\title{
Defining One Product Data for a Product
}

\section{Risto Silvola, Arto Tolonen, Janne Harkonen*, Harri Haapasalo and Tarja Mannisto}

Industrial Engineering and Management, University of Oulu, Finland, P.O. Box 4610, FI-90014 University of Oulu, Finland e-mail: risto.silvola@pp2.inet.fi e-mail: Arto.Tolonen@oulu.fi e-mail: Janne.Harkonen@oulu.fi e-mail: Harri.Haapasalo@oulu.fi e-mail: tarja.mannisto@outlook.com *Corresponding author

\begin{abstract}
The growing importance of product data management and master data necessitate companies to have practices for deriving product master data from their corporate strategy. Business drivers need to be understood from the perspective of corporate strategy to capture product master data in relevant systems in a straightforward manner. Ideally master data is created only once and used through the life-cycle of the product. This study clarifies the foundations for determining one product data from corporate strategy. Data definitions are analysed to understand its linkages to business drivers, whereas main business processes are used to support categorisation. The practices of three companies are analysed to understand how business drivers for new products impact product data requirements. The results highlight the importance of business drivers in defining one product data based on the product master data, business-process related product data and IT systems over the product life-cycle.
\end{abstract}

Keywords: One product data; product data; product master data; master data management; strategy; IT systems; Business Information Systems; product life-cycle; business processes.

Reference to this paper should be made as follows: Silvola, R. Tolonen, A., Harkonen, J., Haapasalo, H. and Mannisto, T. (2019) 'Title', Int. J. Business Information Systems, Vol. 30, No. 4, pp.489-520.

Biographical notes: M.Sc. Risto Silvola received his Masters degree in Mechanical Engineering from University of Oulu, Finland. He has worked for leading global manufacturers at several different positions both in Business organisation and in IT unit. During his career, he has participated in new product programs, global business change programs in program management positions. Currently he is working in the final stages of his long-term dream, finalising postgraduate studies where he combines 20 years of experience working on the field with theory. Aim is to build up a solid big picture of data management of products/services.

Dr Arto Tolonen has received both his MSc in engineering and Dr (Tech) in Industrial Engineering and Management from the University of Oulu, Finland. Currently he is a senior researcher in Industrial Engineering and Management at the University of Oulu. His research interests cover, product management, service management, current challenges and preconditions for product portfolio management and more importantly how to improve PPM practices over life-cycle. The viewpoints include processes, tools, governance models, targets and key performance indicators. $\mathrm{He}$ has over 20 years of experience in development of business processes and operational management of Design for Excellence product design principles and product data management in global companies.

Dr Janne Harkonen received his Bachelor's degree (1st Class Honours) in Engineering Business Management from University of Greenwich in the UK and both his M.Sc. in Process Engineering and Dr (Tech) in Industrial Engineering and Management, from the University of Oulu, Finland. He has also studied in the University of North Carolina at Wilmington, USA. He has worked for several years in the IT and environmental technology industries, in the UK and in Finland. Currently, he is a senior research fellow at the University of Oulu. Dr Harkonen has authored and co-authored over fifty journal articles, and also a number of other publications. 
Dr Harri Haapasalo is the Professor of Product Management at Industrial Engineering and Management, University of Oulu in Finland. He has two main areas of research; one in product management, product development and second one in area of complex systems management, lean construction and business models. Professor Haapasalo has been very active in obtaining research projects, and active in journal publications. His list of publications contains more than 200 international items. He has supervised more than twenty doctoral theses and been external examiner for more than twenty doctoral dissertations.

Tarja Männistö received her M.Sc. (Tech) in Industrial Engineering and Management from the University of Oulu. Currently she works in international retail business in Finland and Germany. Her key interest points include business process management, logistics and data management.

\section{Introduction}

Master data management (MDM) focuses on business processes, data quality and standardisation and integration of information systems (Joshi, 2007). MDM is defined as an application-independent process that describes, owns and manages core business data entities (Otto and Reichert, 2010; Smith and McKeen, 2008). Although MDM has been one of the most topical issues in the field of information systems (Cleven and Wortmann, 2010), it has only recently started attracting the required scientific attention (Otto, 2012; Vilminko-Heikkinen and Pekkola, 2017).

Master data represents a company's key business objects that form the foundation of the company's business purpose and must be used unambiguously across the entire organisation (Otto, 2012). High-quality master data, including supplier and customer information, is necessary to meet strategic business goals, such as better decision making (Haug et al., 2011), integrated customer management (Otto, 2012), compliance with laws and regulations (Hüner et al., 2011) and effective supply-chain management (Hazen et al., 2014). Operating with valid master data helps improve company performance (Arlbjørn et al., 2007). Data quality, hence, is an important aspect of master data (Otto et al., 2011; Silvola et al., 2016). Also, organisations' capabilities play a factor in relation to data quality (Caballero et al., 2008). Focusing on key business objects at different levels and stages of the organisation can help practitioners to improve data quality (Ofner et al., 2013; Shahin, 2014). Hence, master data and its quality has great importance for companies, with true business value.

Product design phase is influenced by many business drivers, requirements that affect operations, and therefore requires well-defined product master data. (Rumelt, 1980; Stiles, 2001; Wu et al., 2014). Sales, after sales, manufacturing and logistics are some of the business phases, like product design. Each of these phases can make master data management very complex in real life (CIMdata, 2002). These complexities are due to silos in the organisational structure, differing interests and lack of common processes or practices (Cooper, 1997; Puzey and Latham, 2016). Fundamental to data management is the alignment of business priorities and a business-specific flexibility without comprising on data quality (CIMdata, 2002). A drawback with the discussions on master data is that they do not emphasise one product data considerations (e.g. Silvola et al., 2011). That is, ideally, the master data is created only once and used in business processes throughout the life-cycle of the product. Thus, the benchmark of good master data is that it does not 
require any modifications later. However, the literature does not address the holistic considerations of product master data in the context of business processes and IT systems.

A key problem with ensuring good product-related master data is that the holistic practices of deriving master data from the corporate strategy are deficient in many companies. Extant literature mostly focuses the alignment between data governance and compliance with corporate strategy (Weber et al., 2009; Wende, 2007). Although Yeoh and Koronios (2010) and Wynn and Brinkmann (2016) recognise the importance of synergy with the corporate strategy, they do not discuss it in the master data context. Some authors such as Schierholz et al. (2007) have addressed the design of customer relationship management (CRM) solutions in conjunction with the goals defined by the corporate strategy. However, not much literature is available on the best practices for defining good data from different business perspectives, which include master data. This is despite the fact that the importance of product data management (PDM) and master data is growing steadily, in line with the focus on data (Saaksvuori and Immonen, 2008).

Many studies cover the corporate strategy process on its own, whereas others discuss master data; however, few combine both the concepts. This study aims to show that when business drivers are understood from the perspective of corporate strategy, setting up master data for a product (in a PDM/PLM system) can become a straightforward process. Sharing the most relevant data with operational systems, such as CRM, enterprise resource planning (ERP), configurators and service business systems is a businessenabling practice. Targets defined in corporate strategy are potentially the underlying motivations for master data activities.

The above discussion can be consolidated into the following research questions:

RQ1. How are product data requirements defined for a new product from a business perspective?

RQ2. How do product business drivers, requirements that affect operations, impact the product data requirements of a new product?

RQ3. How can the concept of one product master data be defined to meet the business drivers?

To answer these research questions, we first review the existing literature to gain an adequate understanding of product master data and its sources. The practices of three different types of companies are then analysed to further understand how new product business drivers impact product data requirements.

\section{Literature review}

\subsection{Company strategy}


The competitive advantage of a company can stem from its products, technology or customer orientation (Keshavarz et al., 2014; King et al., 2010). Each company should articulate its competitive advantage as clearly as its company strategy, which is the basis for performance management and business process alignment (Bai and Sarkis, 2013; de Boer et al., 2015; de Lima et al., 2012; de Morais et al., 2014; Haapasalo et al., 2006; Harmon, 2006; King et al., 2010). One of the key success factors for companies is how they develop their corporate strategy. In practice, this means that the better the strategy process, which includes execution, the more straightforward it is to achieve the set targets (Drucker, 2011).

The strategy process includes the following three key elements: (1) corporate strategy, which describes the direction of the company, influences the profitability and stability of the company and how the management of the business units or lines will be organised (Rumelt, 1980; Stiles, 2001; Sung et al. 2017); (2) business strategy outlines workflows and processes within certain business units or product lines and also identifies improvements for actions described in the business strategy (Rumelt, 1980; Smith and Reece, 1999); and (3) functional strategy deals with managing certain functions, maximising productivity and improving competitive advantage (Fine and Hax, 1985; Rajarathinam et al., 2015; Rumelt, 1980). These strategy processes have dependencies linked to hierarchy, where the top-down model is the standard execution model of the strategy process (Varadarajan, 1994; Wheelen and Hunger, 2006).

In addition to the above elements, incorporating market strategy, product strategy and IT strategy into the strategy process (Figure 1) provides a good framework to understand the hierarchy of the data required for new product development (NPD) (Harris, 1996). This ties in with the well-known triangle of processes, data and IT, which form the basis of managing data (Kropsu-Vehkapera et al., 2009; Silvola et al., 2011). A balanced triangle is necessary because, for example, IT alone cannot provide a sustained competitive advantage (Arora and Rahman, 2017).

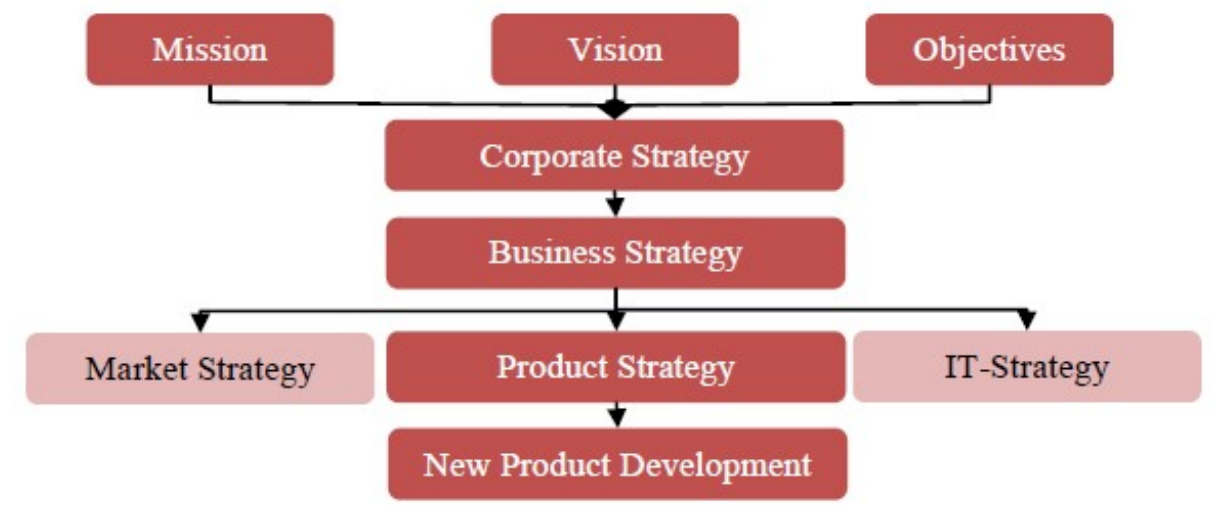

Fig. 1. Business strategy is mainly executed in 3 functional strategies: Product, Market and IT.

H1: Determining one product data from corporate strategy requires considering the key elements of the strategy process, where business strategy is mainly executed via three functional strategies of product, market and IT, in line with the data hierarchy model in $N P D$. 


\subsection{Business processes and product data requirements}

Business processes create value (Addo-Tenkorang and Helo, 2014; DeToro and McCabe, 1997; Neubauer, 2009; Margherita, 2013) through activities such as product development, marketing, sales, manufacturing, logistics and services (Corallo et al., 2010, Gunasekaran and Sandhu, 2010; Malihi and Aghdasi, 2014; Margherita, 2013) in order to meet customer needs and requirements (Kock, 2005; Lee and Dale, 1998). The processes also respond to changing business requirements (de Morais et al., 2014; Kohlbacher, 2010; Monk and Wagner, 2009; Neubauer, 2009) by setting common targets (de Lima et al., 2012; Gardner, 2004; Hammer, 2002; Harmon, 2006; Kersten and Verhoef, 2003; Madison, 2005).

According to Tolonen et al. (2015a), the role of product portfolio management (PPM) is to define what the company products are according to PPM targets and key performance indicators (KPIs) (Figure 2). Traditional business processes define how the products are developed, marketed, sold, delivered, implemented and maintained (Tolonen et al. 2015a). Today, business processes and PPM are interlinked, necessitating a governance body for strategic product portfolio decisions to cover all key processes and company functions as product decisions influence all aspects of the business (Cooper et al., 2001; Meeamol et al., 2011).

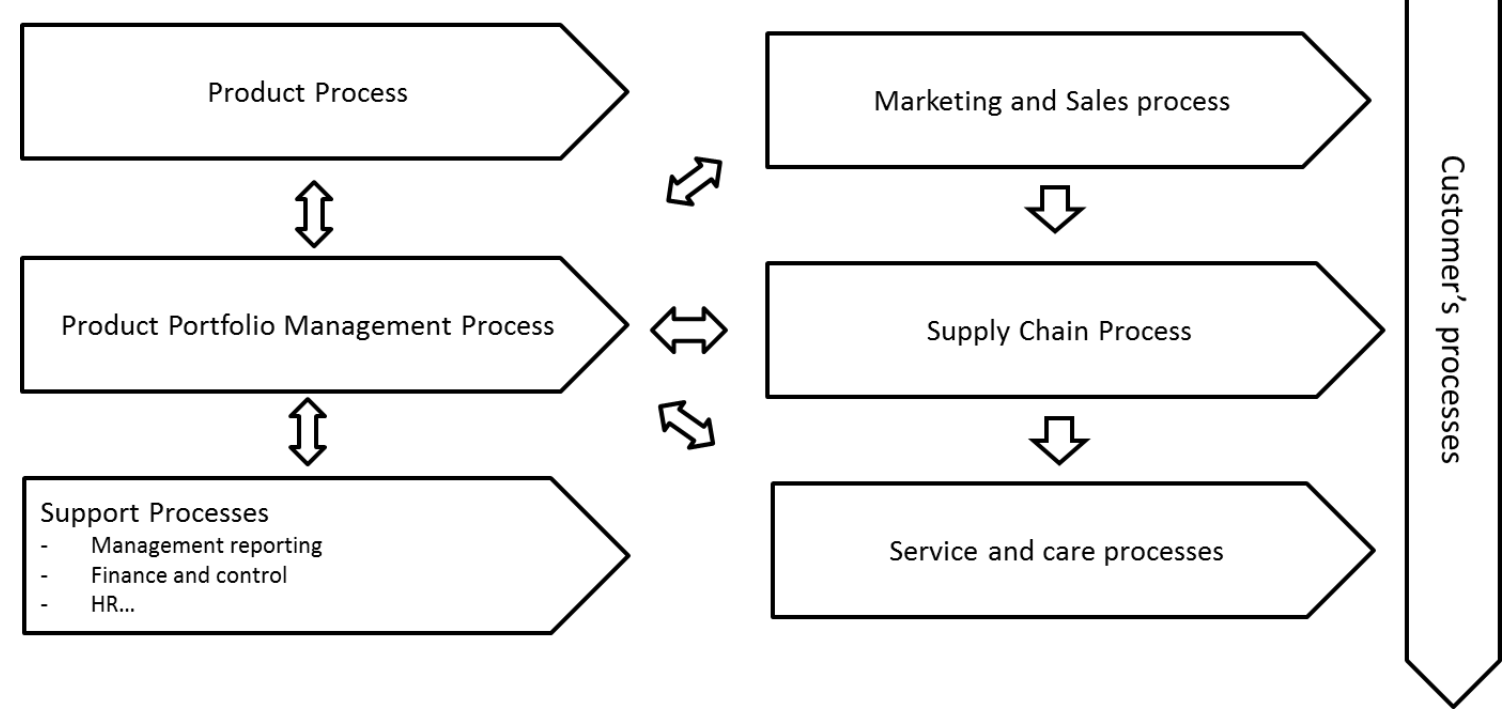

Fig. 2. The structure of the business processes and their relation to product portfolio management

In a product portfolio, which consists of all the company's products, product data is categorised by various parameters ("views"), such as customer segments; technology generations; product families; product types such as hardware, software; and services (Kropsu-Vehkapera and Haapasalo, 2011). Intangible service products are considered heterogeneous because of the involvement of customer activities during the service 
processes (Edvardsson et al., 2005; Lovelock and Gummesson, 2008; Kropsu-Vehkapera et al., 2010). Because service products are experienced by the customer, the exact value of a service product is difficult to determine (Johnston and Clark, 2001).

PPM collects data for analysis and decision-making by considering multiple factors such as uncertainty, dynamic opportunities, markets, customers, technologies and interdependencies between portfolio items. It helps obtain clear product decisions based on strategic targets and criteria defined by the executive level cross-functional management (Cooper et al., 1999; Haines, 2009; Leffingwell, 2007; Weerd et al., 2006). Cooper (2008) emphasises the importance of the stage-and-gate approach to portfolio management, where the gates have "teeth" to acquire better data, while the gates define what information is required from the project team. One of the PPM targets is to extend strategic decision-making over product generations by combining strategy, performance management and business development processes (Bruch and Bellgran, 2014). In fact, the best performing companies may direct about $40 \%$ of their product development investments and resources to totally new products and innovations (Cooper et al., 2004).

People who create product master data should understand that their actions affect a number of people as well as downstream life-cycle phases in the organisation (KropsuVehkapera, 2012). They should understand the product data they are working with. If the product data content is not understood, the quality or purpose of using the product data across IT systems for other business processes is adversely affected (Kemppainen, 2010). Key internal stakeholders for creating product master data are (1) sales and marketing (sales and sales support), (2) supply chain (SC) (demand/supply planning, sourcing, manufacturing, delivery and billing), and (3) after-sales (Kropsu-Vehkapera and Haapasalo, 2011). In this study, the after-sales product data is defined as service and care process related product data.

H2: PPM supports the one data idea by promoting the understanding that ideally the master data is created only once and then used by multiple business processes and IT systems. Thus, PPM has an important relation to product master data via business processes.

\subsubsection{Product data requirements for marketing and sales}

For product data to be used in the sales and marketing context, it should be easily accessible when providing an offering (Table 1). If a product is technically complex or if there is variation in the product offering, a sales configurator is used to support the product data definition (Salonen, 2006; Salvador and Forza, 2007). To ensure customer buy-in and to support marketing, NPD often relies on data from sales and customers before the starting of actual development.

Table 1. Examples of product data requirements for sales and marketing

\begin{tabular}{lll}
\hline $\begin{array}{l}\text { Sales \& } \\
\text { Marketing }\end{array}$ & Product Data & Source \\
\hline $\begin{array}{l}\text { Sales and } \\
\text { marketing }\end{array}$ & Sales package description of sales item combinations & $\begin{array}{l}\text { (Baghdadi, 2014; Kropsu-Vehkapera, 2012; } \\
\text { Kropsu-Vehkapera and Haapasalo, 2011) } \\
\text { (Cooper, 2001; Li et al., 2011; Pan et al., 2014; } \\
\end{array}$ \\
& Marketing \& sales plan; customer demand & Tao et al., 2017) \\
& Marketing and sales material (commer, 2001; Kropsu-Vehkapera, 2012; & \\
\cline { 3 - 4 }
\end{tabular}




\begin{tabular}{|c|c|c|}
\hline & technical) \& their legal approvals & $\begin{array}{l}\text { Saaksvuori and Immonen, 2008; Kropsu- } \\
\text { Vehkapera and Haapasalo, 2011) }\end{array}$ \\
\hline & $\begin{array}{l}\text { Product/service pricing and customer deal } \\
\text { instructions }\end{array}$ & $\begin{array}{l}\text { (Cooper, 2001; Baghdadi, 2014; Kropsu- } \\
\text { Vehkapera, 2012; Saaksvuori and Immonen, } \\
\text { 2008; Sajadfar et al., 2014; Sharma and Shah, } \\
\text { 2015) }\end{array}$ \\
\hline & Launch plan for commercial partners & (Cooper, 2001) \\
\hline & Promotion and launch material & (Kemppainen, 2010) \\
\hline & $\begin{array}{l}\text { Customer requests for product improvements } \\
\text { (product change requirements) }\end{array}$ & (CIMdata, 2002) \\
\hline Configuration & $\begin{array}{l}\text { Configuration guidelines: recommended } \\
\text { configurations, marketing/sales limitations, properties } \\
\text { and features, customer-specific configurations, } \\
\text { price/cost information }\end{array}$ & $\begin{array}{l}\text { (Do et al., 2002; 2008; Kropsu-Vehkapera, } \\
\text { 2012; Saaksvuori and Immonen, 2008) }\end{array}$ \\
\hline & Pre-set configuration rules & $\begin{array}{l}\text { (Jinsong et al., 2005; Li et al. 2016; Saaksvuori } \\
\text { and Immonen, 2008) }\end{array}$ \\
\hline & $\begin{array}{l}\text { Delivery times and sales channels for saleable } \\
\text { products }\end{array}$ & $\begin{array}{l}\text { (Kropsu-Vehkapera, 2012; Silvola et al., 2016; } \\
\text { Tu et al., 2006) }\end{array}$ \\
\hline & $\begin{array}{l}\text { Specific customer discounts (Customer contracts as a } \\
\text { reference) }\end{array}$ & $\begin{array}{l}\text { (Kropsu-Vehkapera, 2012; Kropsu-Vehkapera } \\
\text { and Haapasalo, 2011) }\end{array}$ \\
\hline & Customer service descriptions & $\begin{array}{l}\text { (Kropsu-Vehkapera, 2012; Kropsu-Vehkapera } \\
\text { and Haapasalo, 2011) }\end{array}$ \\
\hline Sales support & $\begin{array}{l}\text { Internal work instructions for product-specific } \\
\text { questions }\end{array}$ & $\begin{array}{l}\text { (Kropsu-Vehkapera, 2012; Kropsu-Vehkapera } \\
\text { and Haapasalo, 2011) }\end{array}$ \\
\hline & $\begin{array}{l}\text { Internal product guidelines, system and realisation for } \\
\text { reconfiguring products }\end{array}$ & $\begin{array}{l}\text { (Kropsu-Vehkapera, 2012; Kropsu-Vehkapera } \\
\text { and Haapasalo, 2011) }\end{array}$ \\
\hline
\end{tabular}

H3: Product data requirements for marketing and sales can be divided into sales \& marketing, configuration and sales support. Opportunities for swift access are emphasised in the marketing and sales context.

\subsubsection{Product data requirements related to the supply chain process}

In the SC context, product master data is needed to execute various processes (Table 2) such as sourcing, buying, storing, manufacturing, delivering and invoicing (Ofner et al., 2013). From an IT perspective, new SC-related product data attributes are needed, and sometimes the data is revised to ensure optimised actions. For example, lead-time or supplier record are relevant for optimum actions. SC-related product data has considerable impact on the master data, which in turn implies that SC information should be integrated early into the NPD process (Leser et al., 2005). This is because once product design phase is completed, much of the master data cannot be changed from the SC perspective.

Table 2. Examples of product data requirements related to the supply chain

\begin{tabular}{lll}
\hline $\begin{array}{l}\text { Production } \\
\text { process phase }\end{array}$ & Product Data & Source \\
\hline $\begin{array}{l}\text { Demand/Supply } \\
\text { planning }\end{array}$ & Planning frames and product allocation preferences & $\begin{array}{l}\text { (Kropsu-Vehkapera, 2012; Kropsu- } \\
\text { Vehkapera and Haapasalo, 2011) }\end{array}$ \\
& Prioritisation instructions & (Brettel et al., 2014; Kropsu-Vehkapera, \\
& (Work instructions) & 2012; Kropsu-Vehkapera and Haapasalo, \\
& Information on planned volume ramp-up/ramp-down & (Kropsu-Vehkapera, 2012; Kropsu- \\
& & Vehkapera and Haapasalo 2011; Tolonen \\
\hline
\end{tabular}




\begin{tabular}{|c|c|c|}
\hline & & et al., 2014) \\
\hline \multirow[t]{3}{*}{ Sourcing } & $\begin{array}{l}\text { Purchaser of an item, vendor, lead-times, lot size, order } \\
\text { frequency, purchasing price }\end{array}$ & $\begin{array}{l}\text { (Kropsu-Vehkapera, 2012; Kropsu- } \\
\text { Vehkapera and Haapasalo, 2011; Terzi et } \\
\text { al., 2010; Xiang et al., 2017) }\end{array}$ \\
\hline & $\begin{array}{l}\text { Mode of purchasing of original equipment } \\
\text { manufacturer(OEM) }\end{array}$ & $\begin{array}{l}\text { (Kropsu-Vehkapera, 2012; Kropsu- } \\
\text { Vehkapera and Haapasalo, 2011) }\end{array}$ \\
\hline & $\begin{array}{l}\text { Delivering plant with outsourced service: service } \\
\text { descriptions and local costs }\end{array}$ & $\begin{array}{l}\text { (Kropsu-Vehkapera, 2012; Kropsu- } \\
\text { Vehkapera and Haapasalo, 2011) }\end{array}$ \\
\hline \multirow[t]{9}{*}{$\begin{array}{l}\text { Material } \\
\text { management }\end{array}$} & Component data & $\begin{array}{l}\text { (Johansson and Johansson, 2004; Siddiqui } \\
\text { et al., 2004; Tao et al., 2017; Terzi et al., } \\
\text { 2010; Xiang et al., 2017) }\end{array}$ \\
\hline & Geometrical-dependent data: dimensions & $\begin{array}{l}\text { (Johansson and Johansson, 2004; Terzi et } \\
\text { al., 2010; Johansson and Medbo, 2004) }\end{array}$ \\
\hline & $\begin{array}{l}\text { Geometrical and material data: weight, sharpness, } \\
\text { handling requirements }\end{array}$ & $\begin{array}{l}\text { (Johansson and Johansson, 2004; } \\
\text { Johansson and Medbo, 2004) }\end{array}$ \\
\hline & $\begin{array}{l}\text { Material data: sensitivity to surface material, dust and } \\
\text { temperature, ecological impact, inflammable/explosive }\end{array}$ & $\begin{array}{l}\text { (Johansson and Johansson, 2004; Tao et } \\
\text { al., 2017) }\end{array}$ \\
\hline & $\begin{array}{l}\text { Others: electrostatic discharge (ESD), identifiable, } \\
\text { liable to theft }\end{array}$ & (Johansson and Johansson, 2004) \\
\hline & Product structure groups & $\begin{array}{l}\text { (Johansson and Johansson, 2004; } \\
\text { Johansson and Medbo, 2004; Tao et al., } \\
\text { 2017) }\end{array}$ \\
\hline & $\begin{array}{l}\text { Component variants (interchangeable component in } \\
\text { different variants) }\end{array}$ & $\begin{array}{l}\text { (Johansson, 2007; Johansson and } \\
\text { Johansson, 2004; Johansson and Medbo, } \\
\text { 2004) }\end{array}$ \\
\hline & Parts materials and generic item data & (Li et al., 2011) \\
\hline & Parts batch and number, craft parts information & (Li et al., 2011) \\
\hline \multirow[t]{6}{*}{$\begin{array}{l}\text { Production } \\
\text { Methods }\end{array}$} & $\begin{array}{l}\text { Instructions: manufacturing process guidelines, item } \\
\text { testing etc. }\end{array}$ & $\begin{array}{l}\text { (Kropsu-Vehkapera, 2012; Kropsu- } \\
\text { Vehkapera and Haapasalo, 2011; Tao et } \\
\text { al., 2017; Xiang et al., 2017) }\end{array}$ \\
\hline & $\begin{array}{l}\text { Assembly and parts manufacturing methods, } \\
\text { component assembling process }\end{array}$ & (Li et al., 2011) \\
\hline & $\begin{array}{l}\text { Final producing methods, processing equipment, } \\
\text { tooling }\end{array}$ & (Li et al., 2011) \\
\hline & $\begin{array}{l}\text { Parts, computer-aided process planning, parts } \\
\text { processing operations, parts assembly sequences }\end{array}$ & $\begin{array}{l}\text { (Li et al., 2011) } \\
\text { (Fujimoto et al., 2003) }\end{array}$ \\
\hline & $\begin{array}{l}\text { Production outline and plan, production type, working } \\
\text { hours }\end{array}$ & (Li et al., 2011) \\
\hline & Manufacture resource and workshop & (Li et al., 2011) \\
\hline \multirow[t]{2}{*}{ Delivery } & $\begin{array}{l}\text { Packing instructions: compliance and document } \\
\text { requirements, package identification marking }\end{array}$ & $\begin{array}{l}\text { (Baghdadi, 2014; Kropsu-Vehkapera, } \\
\text { 2012; Kropsu-Vehkapera and Haapasalo, } \\
\text { 2011) }\end{array}$ \\
\hline & $\begin{array}{l}\text { Information on shipping lot size and guidance for pick- } \\
\text { up }\end{array}$ & $\begin{array}{l}\text { (Baghdadi, 2014; Kropsu-Vehkapera, } \\
\text { 2012; Kropsu-Vehkapera and Haapasalo } \\
\text { 2011) }\end{array}$ \\
\hline \multirow[t]{2}{*}{$\begin{array}{l}\text { (Service } \\
\text { delivery/project } \\
\text { execution) }\end{array}$} & $\begin{array}{l}\text { Guidance for service implementation: roles and } \\
\text { responsibilities }\end{array}$ & $\begin{array}{l}\text { (Kropsu-Vehkapera, 2012; Kropsu- } \\
\text { Vehkapera and Haapasalo, 2011; Tao et } \\
\text { al., 2017; Xiang et al., 2017) }\end{array}$ \\
\hline & Pricing reference material for profit calculations & $\begin{array}{l}\text { (Kropsu-Vehkapera, 2012; Kropsu- } \\
\text { Vehkapera and Haapasalo, 2011) }\end{array}$ \\
\hline Billing & Price list, price item and product catalogue & $\begin{array}{l}\text { (Baghdadi, 2014; Kropsu-Vehkapera, } \\
\text { 2012; Kropsu-Vehkapera and Haapasalo, } \\
\text { 2011) }\end{array}$ \\
\hline
\end{tabular}

H4: SC-related product data has considerable impact on master data, which highlights the importance of early inclusion of SC requirements in NPD. The importance of SC process related product data is emphasised by the product master data directly linking to the execution of various vital processes. 
2.2.3 Product data requirements related to the service and care process

Much of the product data related to service and care is derived from the previous product life-cycle phases (Table 3). If the product data from the previous phases is up-to-date, it facilitates easier after-sales transactions (Terzi et al., 2010). It is essential to define the product data related to service and care during the product development phase (KropsuVehkapera, 2012). There is often a link between the master data of the SC phase and the service and care phase.

Table 3. Examples of product data requirements for service and care process

\begin{tabular}{|c|c|}
\hline Product data & Source \\
\hline Product error correction plans and roadmaps & $\begin{array}{l}\text { (Kropsu-Vehkapera, 2012; Kropsu- } \\
\text { Vehkapera and Haapasalo, 2011) }\end{array}$ \\
\hline Service levels & (Ala-Risku, 2009) \\
\hline Instructions for troubleshooting, testing and system set-ups & $\begin{array}{l}\text { (Kropsu-Vehkapera, 2012; Kropsu- } \\
\text { Vehkapera and Haapasalo, 2011) }\end{array}$ \\
\hline Secure access to information for local contracting partners & (Saaksvuori and Immonen, 2008) \\
\hline $\begin{array}{l}\text { User privileges and information security (second sources product } \\
\text { specifications data etc.) }\end{array}$ & $\begin{array}{l}\text { (Saaksvuori and Immonen, 2008; Stark, } \\
\text { 2004) }\end{array}$ \\
\hline Customer service documentation/information & $\begin{array}{l}\text { (Li et al., 2011; Saaksvuori and Immonen, } \\
\text { 2008) }\end{array}$ \\
\hline Customer's product structures & $\begin{array}{l}\text { (Li et al., 2011; Saaksvuori and Immonen, } \\
\text { 2008) }\end{array}$ \\
\hline $\begin{array}{l}\text { Item bill of materials (BOMs) for material orders, spare parts, remote } \\
\text { maintenance, technical support }\end{array}$ & $\begin{array}{l}\text { (Ala-Risku, 2009; Saaksvuori and } \\
\text { Immonen, 2008) }\end{array}$ \\
\hline Spare part manual & (Saaksvuori and Immonen, 2008) \\
\hline Technical manuals & (Pham et al., 1999; Stark, 2004) \\
\hline Sales or delivery project documents for modernisations & (Ala-Risku, 2009) \\
\hline Accessories sales information & (Li et al., 2011) \\
\hline Product documents and manuals for technical support & (Ala-Risku, 2009) \\
\hline Maintenance handling tools and needed skills & (Stark, 2004) \\
\hline Field data management & (Stark, 2004) \\
\hline Maintenance plans, warranty issues & (Ala-Risku, 2009; Stark, 2004) \\
\hline Performance data maintenance for preventive maintenance plan & (Stark, 2004) \\
\hline Software correction packages and information on new software releases & $\begin{array}{l}\text { (Kropsu-Vehkapera, 2012; Kropsu- } \\
\text { Vehkapera and Haapasalo, 2011) }\end{array}$ \\
\hline Change information for products and supporting infrastructure & $\begin{array}{l}\text { (Kropsu-Vehkapera, 2012; Kropsu- } \\
\text { Vehkapera and Haapasalo, 2011) }\end{array}$ \\
\hline Information about the versions of manufactured and delivered products & (Saaksvuori and Immonen, 2008) \\
\hline $\begin{array}{l}\text { original equipment manufacturer, manufacturing data, bills of materials, } \\
\text { operational conditions, usage plans }\end{array}$ & (Ala-Risku, 2009) \\
\hline Prior service data & (Ala-Risku, 2009; Xiang et al., 2017) \\
\hline
\end{tabular}

H5: Product data relevant to the service and care process covers product installation and the care and repair life-cycle. It highlights the importance of providing up-to-date data to support service and care transactions. Acknowledging the needs of service and care during NPD is also essential.

\subsubsection{Functional and technical requirements for product data}

Actual product data requirements (Table 4) can be divided into two main categories: (1) functional and (2) technical (Nilsson and Fagerstrom, 2006). Functional product data requirements refer to the ability of the product data to support value creation and business optimisation, and they are influenced by the life-cycle of the product. Technical product 
data requirements are derived from IT system requirements and from data quality principles to facilitate functional product data requirements.

Table 4. Universal product data quality requirements towards realising one product master data

\begin{tabular}{|c|c|}
\hline Universal, product data quality requirements & Source \\
\hline Data accuracy and objectivity, reliability and reusability & $\begin{array}{l}\text { (Saravanan and Joseph, 2016; Stark, } \\
\text { 2004) }\end{array}$ \\
\hline $\begin{array}{l}\text { Data accessibility and availability (privileges, protection), data security, data } \\
\text { authentication and encryption }\end{array}$ & $\begin{array}{l}\text { (Chauhan and Jaiswal, 2015; } \\
\text { Kropsu-Vehkapera, 2012; Lee and } \\
\text { Suh, 2009; Philpotts, 1996; Stark, } \\
\text { 2004; Wang and Strong, 1996) }\end{array}$ \\
\hline Data believability and reputation & $\begin{array}{l}\text { (Silvola et al., 2016; Wang and } \\
\text { Strong, 1996) }\end{array}$ \\
\hline Data consistency (well organised and structured, levelled) & $\begin{array}{l}\text { (Philpotts, 1996; Sharma et al., } \\
\text { 2016; Stark, 2004) }\end{array}$ \\
\hline Data context, format and meaning & (Wang and Strong, 1996) \\
\hline $\begin{array}{l}\text { Data control: master for a piece of data; change and product configuration } \\
\text { management }\end{array}$ & (Stark, 2004) \\
\hline $\begin{array}{l}\text { Data system integrations and closed-loop information flow (transparent and } \\
\text { bidirectional), data links and relationships to source and derived data, } \\
\text { navigation through links }\end{array}$ & $\begin{array}{l}\text { (Lee and Suh, 2009; Philpotts, } \\
\text { 1996; Saaksvuori and Immonen, } \\
\text { 2008; Stark, 2004) }\end{array}$ \\
\hline $\begin{array}{l}\text { Data interface management, interoperation of data representations with } \\
\text { standardised data between devices }\end{array}$ & (Lee and Suh, 2009; Stark, 2004) \\
\hline Maintenance and documentation issues of data & (Stark, 2004) \\
\hline Data ownership issues: roles, rights and responsibilities, definitions & $\begin{array}{l}\text { (Kropsu-Vehkapera, 2012; Otto, } \\
\text { 2012; Silvola et al., 2011; 2016; } \\
\text { Stark, 2004) }\end{array}$ \\
\hline $\begin{array}{l}\text { Data is presented in the correct view and form, different representations for } \\
\text { different users }\end{array}$ & $\begin{array}{l}\text { (Kropsu-Vehkapera, 2012; Stark, } \\
\text { 2004) }\end{array}$ \\
\hline $\begin{array}{l}\text { Standard underlying data: consistent, uniform definition of product, unified } \\
\text { data model }\end{array}$ & $\begin{array}{l}\text { (Kropsu-Vehkapera, 2012; Lee and } \\
\text { Suh, 2009; Silvola et al., 2011; } \\
\text { Stark, 2004) }\end{array}$ \\
\hline Data processes are clearly defined & (Silvola et al., 2011) \\
\hline Data storable in different formats, in different systems & (Philpotts, 1996) \\
\hline Proactive data surveillance & (Silvola et al., 2011) \\
\hline Important system component in place & (Stark, 2004) \\
\hline Data traceability & $\begin{array}{l}\text { (Lee and Suh, 2009; Li et al., 2011; } \\
\text { Stark, 2004) }\end{array}$ \\
\hline $\begin{array}{l}\text { Real-time data acquisition, up-to-date data through updates, correct data } \\
\text { versions }\end{array}$ & $\begin{array}{l}\text { (Lee and Suh, 2009; Philpotts, } \\
\text { 1996; Saaksvuori and Immonen, } \\
\text { 2008; Stark, 2004) }\end{array}$ \\
\hline Data usability and usefulness, data retrieval & $\begin{array}{l}\text { (Philpotts, 1996; Strong et al., } \\
\text { 1997) }\end{array}$ \\
\hline
\end{tabular}

H6: Ensuring that data supports value creation and business optimisation (functional data requirements) and that the IT system requirements and data quality principles (technical product data) enable such support are vital for one product data.

\subsection{Business process applications and the nature of the data}

Business processes require integration of information systems to ensure process control, performance management and updating internal and external stakeholders (Genaroro and Lourero, 2015; Tian and Quan, 2008). PDM systems can be used efficiently for the creation of configurable and modular products by the automation of the product data integrations (Ulrich and Eppinger, 2012; Williams, 2008), enabling a number of different solutions for customers through a minimum number of items in the portfolio (Gosling 
and Naim, 2009; Hvam et al., 2008). The ability to manage key data is critical (Mani et al., 2013). The preconditions for company-wide MDM include product data models and nominated product data owners who ensure controlled product data quality (Silvola et al., 2011). The existing IT-based product life cycle management (PLM) solutions are designed to provide better support to data management activities during the NPD phase than over the entire life-cycle (Saaksvuori, 2011). However, product data attributes are managed not only by PDM systems but also systems such as ERP (Gomez et al., 2014; Sonzini et al., 2015; Sriti et al., 2015; Tidstam and Malmqvist, 2015).

The main IT systems needed during the product life-cycle include the CRM, ERP and service/care systems. A CRM system maintains records of interactions with current and possible new customers (Gomez et al., 2014; Meyliana et al., 2016; Silvola et al., 2011; Saaksvuori, 2011; Stark, 2004; Tian and Quan, 2008). Data stored in the CRM system covers the life-cycle of the interactions. An ERP system covers the main business processes such as manufacturing, planning, marketing, sales, shipping and invoicing. ERP is a core system for the business transactions (Jain, 2016). Service/care systems are used to offer customer support and maintenance services, typically for after-sales purposes. Examples of after-sales services include scheduled maintenance, providing spare parts and upgrades (Stark, 2004).

H7: One product data considerations can benefit of the effective use of information systems to integrate business processes. PDM, PLM, CRM, ERP and service/care systems have clear roles in the creation of product master data.

\subsection{Synthesis}

Product master data refers to data that is produced during the NPD phase-it is then released for use in other corporate functions and business processes. Common data, on the other hand, is the data that is often discussed in literature-whose relationship with the business processes varies to a great extent. Common product data should, however, be maintained in PDM/PLM systems and should be shared by all the business processes to ensure that it is uniformly used. (Figure 3 ).

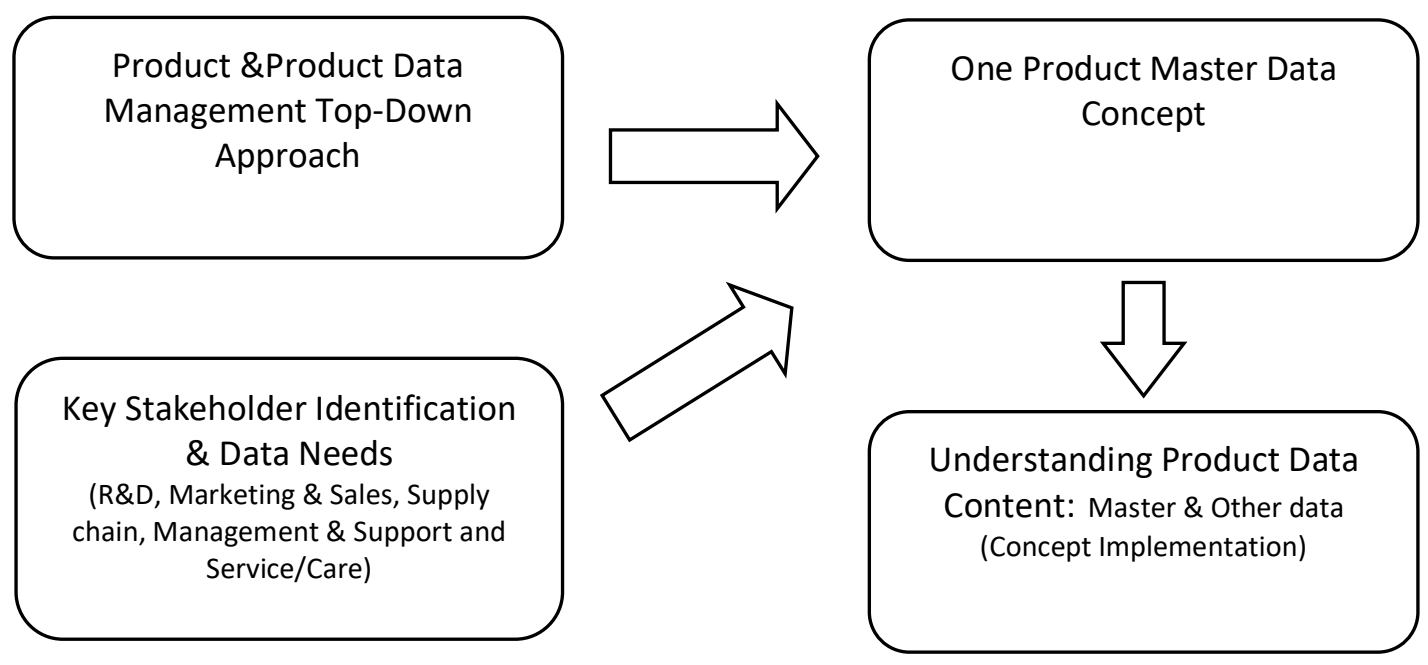


Fig. 3. The role of the common - harmonised one product data for business processes.

Scheidt and Zong (1994) state that product data can be either static or dynamic by its nature. Static data merely has a longer life-cycle than the dynamic data. Crnkovic (2002) talks about business drivers that are maintained and stored in the PDM/PLM solution. Alignment between strategy, business drivers, and product master data is vital for the business performance (McGrath, 2001; Tolonen et al., 2015b). Figure 4 shows a simplified process flow illustrating how product master data can be derived from customers and corporate strategy. The process flow indicates that repeated discontinuations in the flow will adversely affect the product master data, the performance of the product and thus the company in the later phases of the product lifecycle.

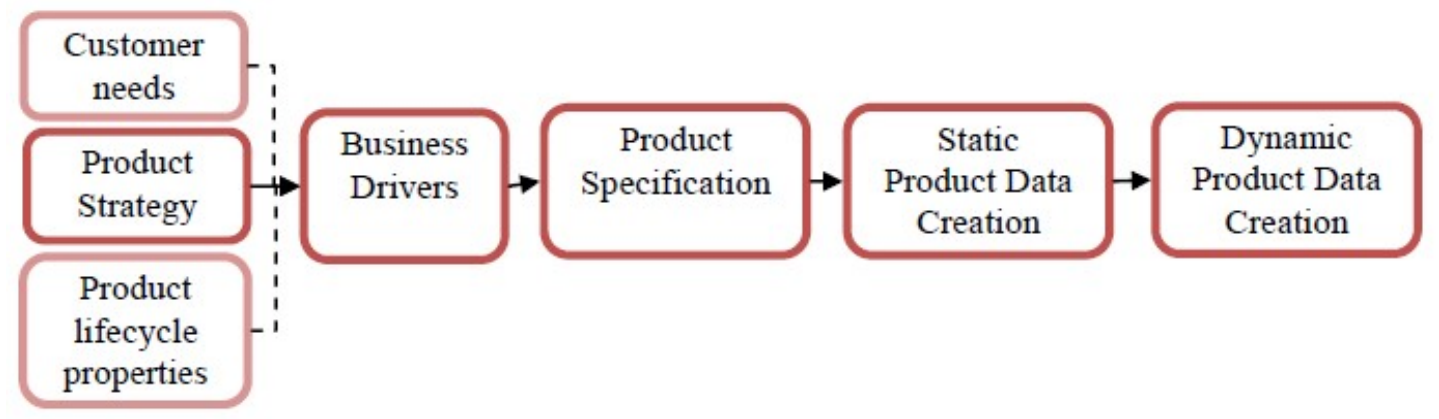

Fig. 4. Simplified process flow from corporate strategy to product master data management

H8: The concept of one product master data can support the understanding of common product data. Further, it supports the development of links between strategy, business drivers, and the product master data.

\section{Research method and description of case companies}

The study uses two qualitative research methods: extensive literature review and interviews with relevant company representatives. Figure 5 illustrates the research process. Firstly, an initial literature review was conducted on the topics of MDM, PDM, PLM, business drivers, strategy and product design to understand how one product data can be determined from corporate strategy. Relevant hypotheses were developed. The literature analysis also helped conceptualise product master data and the business factors that require master data. An overview was obtained about how different authors view corporate strategy as the source of the business drivers of product data.

Secondly, empirical data collection was carried out to better understand the business drivers emerging from corporate strategy. A formal and an informal interview guide were developed based on the literature findings and used for company selection and the interviews. Company A was interviewed first and the relevant confidential data were obtained. We analysed company A first because it is a leading player in its field and 
possibly has advanced master data and product data practices. The data from company A were carefully analysed to understand how new product business drivers impact the product data requirements. The analysis included identifying and analysing business drivers, and further noting the commonality and impact on product data requirements.

Two additional companies (B and C) were selected from different sectors, they were interviewed and confidential material was obtained. The empirical results of these interviews were carefully analysed, and the practices were compared to those of company A. Next, the findings were analysed in light of existing literature. This was followed by a second set of interviews with company A representatives to confirm the earlier findings and to obtain further insights into the practices of the other two companies. Final analyses were conducted using all the obtained material and conclusions were drawn.

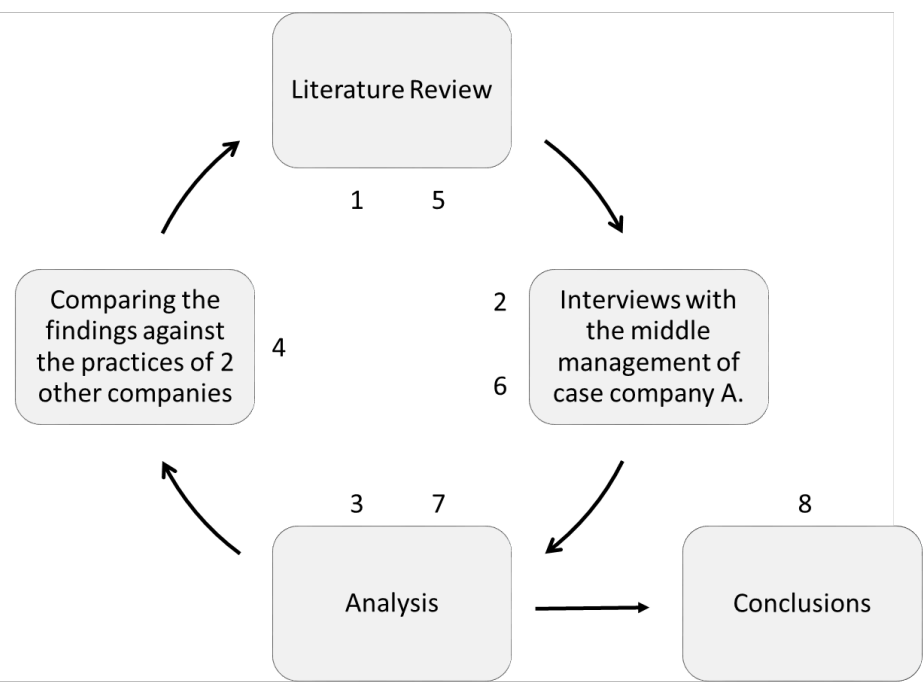

Fig. 5. Research process of this study

A sample size of three companies was considered adequate to the aims of the study (Patton, 2002; Siggelkow, 2007). Company A was intentionally selected as the main case while the others played the role of reference points (Table 5). The quality of the input data was an important criterion for selecting the companies, along with some access to influential individuals within.

Table 5. Characteristics of the companies.

\begin{tabular}{llllll}
\hline Company Product type & $\begin{array}{l}\text { Business } \\
\text { life-cycle } \\
\text { stage }\end{array}$ & $\begin{array}{l}\text { Business } \\
\text { type }\end{array}$ & Markets & $\begin{array}{l}\text { \# of interview sessions } \\
\text { and informants }\end{array}$ \\
\hline A & HW, Services & Growth & B2B & Global & 5 sessions, 12 informants \\
B & Services & Mature & B2B, B2C & Regional & 1 session, 2 informants \\
C & Food & Growth & B2B, B2C & Regional & 1 session, 2 informants
\end{tabular}

Company A is a leading global manufacturer of heavy machinery. Headquartered in Finland with over 10,000 employees worldwide, the company was an appropriate 
case for the study as its product portfolio and service offerings suggest that data issues are highly relevant to it. Company A operates in business-to-business (B2B) and business-to-consumer (B2C) markets, providing equipment and services to a variety of companies and has a revenue of several billions. Data relevant to company A's products and services is tracked and controlled by IT processes. The company has witnessed several major business process and IT renewal programmes in the past five years. Interviews with company A covered members of the middle management: product managers (4), research and development (R\&D) managers (3), chief engineers (3), architects (IT), and PLM concept owners.

The other two companies in this study are reference points. They were included to better understand whether the findings from company A are indicative of a larger trend. The companies were selected such that none are in direction competition with the other, which allowed for open discussion on topics.

Company B operates in the service sector, undertaking many internet of things (IoT) initiatives. Its operations are limited to Scandinavia but it provides large complex IT services to both B2B and B2C customers. Two middle management employees were interviewed in company B: a product manager (1) and a R\&D manager (1).

Company $\mathrm{C}$ operates in the food manufacturing sector, selling its products to tens of countries and has a revenue of a few billions. The company's business offerings include product and technology exports and significant innovations. We interviewed a product manager (1) and a $R \& D$ manager (1) at company $C$.

The interviews were semi-structured, allowing respondents to explain the topics as entities (Merton et al., 1990). Interviews were supplemented by personal observations, confidential company material and secondary data. The availability of abundant analysed material enabled triangulation and cross-verification of findings (Yin, 2003). Triangulation of data improved the reliability of the research (McCutcheon and Meredith, 1993). Versatile data sources linked together with a clear chain of evidence helped establish construct validity. Although the same research protocol was used in the interviews, the focus of each interview was somewhat influenced by the respondent and their perspective. The content and logic of the interviews were reviewed before and after the interviews to establish a chain of evidence. Responses were recorded and transcribed to enable thorough analyses, while a research protocol and the development of a case study database helped ensure the reliability of the study (Yin, 2003).

\section{Empirical analysis of the business drivers (requirements) for product data}

\section{Company $A$}

Business drivers were analysed to understand how they impact product data requirements (Table 6). Further analysis showed that $17(63 \%)$ business drivers were common (Fig 6) to all the product categories and should be defined clearly during the NPD phase. Changing these drivers later is not possible as they define the product 
itself - "the DNA of the product". Noteworthy is that these drivers apply across all the product categories.

Company A has three different types of operational models: engineer-to-order (ETO), configure-to-order (CTO), and make-to-order (MTO) and related products. Four $(15 \%)$ of the company's business drivers were category-specific, i.e. ETO, CTO or MTO. Six (22\%) had low impact on NPD and could be added, or changed in the later phases of the product life-cycle (Fig 6). In total, 27 business drivers were identified in the interviews with company A.

Table 6. Business drivers identified in interviews with company A.

\begin{tabular}{|c|c|c|}
\hline & Business Drivers & Execution extremes \\
\hline 1 & Product branding & Multiple / one brand strategy \\
\hline 2 & Design point for additional/ changeable features & Before launch / after launch \\
\hline 3 & Multi-location product design & Yes / No \\
\hline 4 & Product design ownership (PDCP) & Intellectual property rights not owned / Owned \\
\hline 5 & Level of purchased PMCPs in product & High / Low \\
\hline 6 & Make or buy & In-house / Outsourced \\
\hline 7 & Product modularity incl. & Utilised / Not utilised \\
\hline 8 & Utilisation of scale tech parts & Utilised / Not utilised \\
\hline 9 & Custom requirements & High / Low \\
\hline 10 & Final assembly plan & Needed / Not Needed \\
\hline 11 & Specified transportation concept & Needed / Not Needed \\
\hline 12 & Cost control criticality (Product) & Critical / Non-critical \\
\hline 13 & $\begin{array}{l}\text { Product design upgradability later during life- } \\
\text { cycle }\end{array}$ & High / Low \\
\hline 14 & Product manufacturing location & Multi-location / One location \\
\hline 15 & Invoicing possibilities & Multiple / One \\
\hline 16 & $\begin{array}{l}\text { Execution of customer-specific product } \\
\text { requirements }\end{array}$ & High / Low \\
\hline 17 & Product volume & Volume / Unique \\
\hline 18 & Customer-specific documentation requirements & High / Low \\
\hline 19 & Customer documentation creation & Automated / manual \\
\hline 20 & Product configuration and automation & Needed / Not needed \\
\hline 21 & Manufacturing documentation creation & Automated / manual \\
\hline 22 & Product traceability requirements & High / Low \\
\hline 23 & After sales possibilities incl. & High / Low \\
\hline 24 & Product modernisation possibilities & High / Low \\
\hline 25 & Spare part management possibilities & High / Low \\
\hline 26 & Global technical support requirements & High / Low \\
\hline 27 & $\begin{array}{l}\text { Possibilities/ Offerings for remote monitoring } \\
\text { services }\end{array}$ & High / Low \\
\hline
\end{tabular}




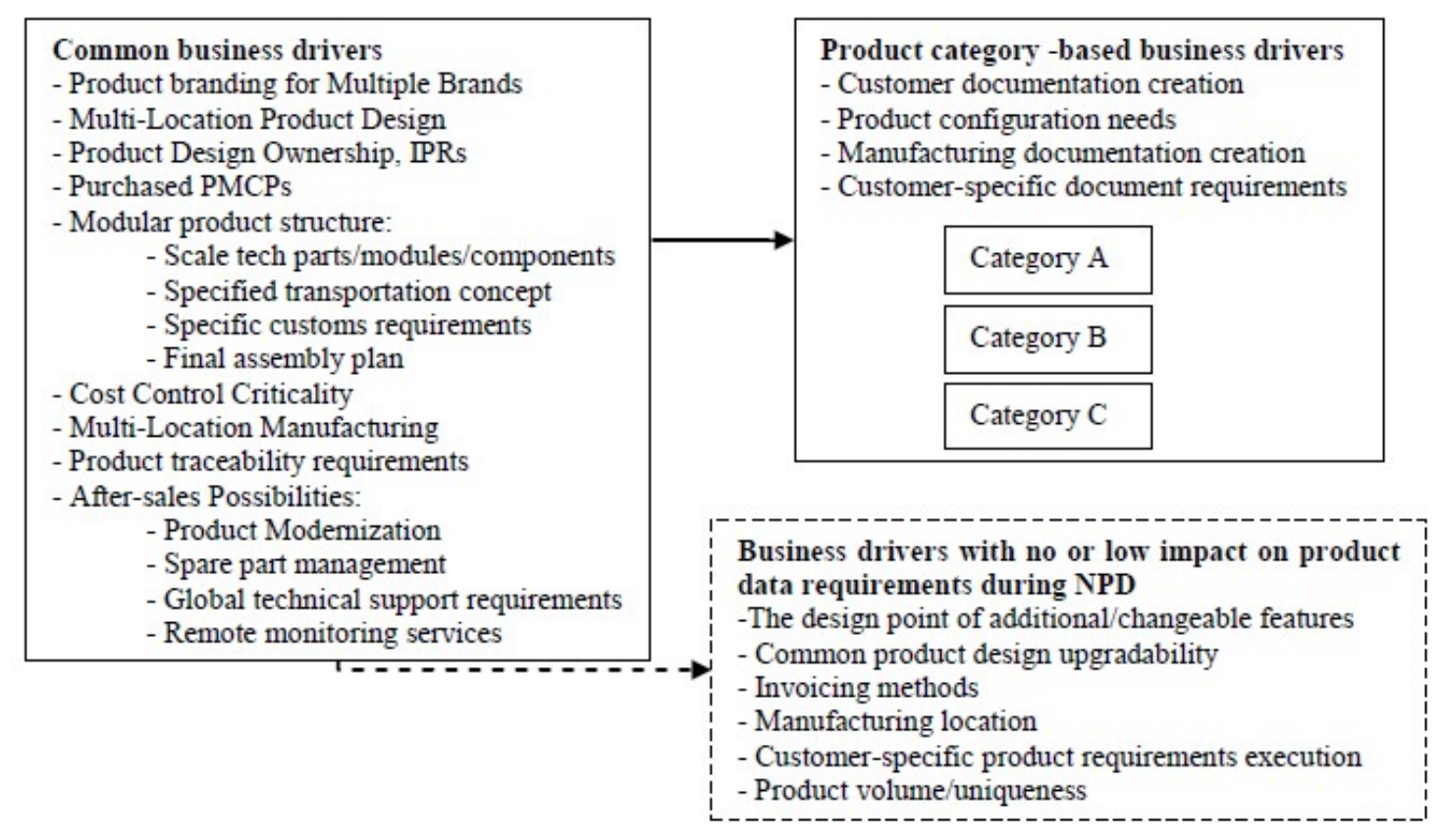

Fig. 6. Common business drivers, category-specific business drivers and low impact drivers.

In company $\mathrm{A}$, some business drivers were well recognised by all the interviewees as they featured repeatedly in their comments (Figure 6, common business driver category).

The interviewees explained that the process of product data definition was somewhat unstructured and non-directed. Product data creation required considerable effort and had to be undertaken separately for several isolated IT systems. Overall, respondents did not seem to understand the gravity of not identifying or achieving the business drivers early in the NPD process. The links between business drivers and master data definition were not well acknowledged.

Clear links between engineering bill of material (BOM), sales BOM and manufacturing BOM were missing in company A; thus, business drivers were not secured prior to product launch. Data reaching the service BOM, especially the master data definitions related to the services and care process, based on business drivers, were not clear from product master data perspective: the links to the original product data were loosely defined. Interviewees from company A recognised the need for improvements in their data processes and were working on them in their ongoing projects (Figure 7). 


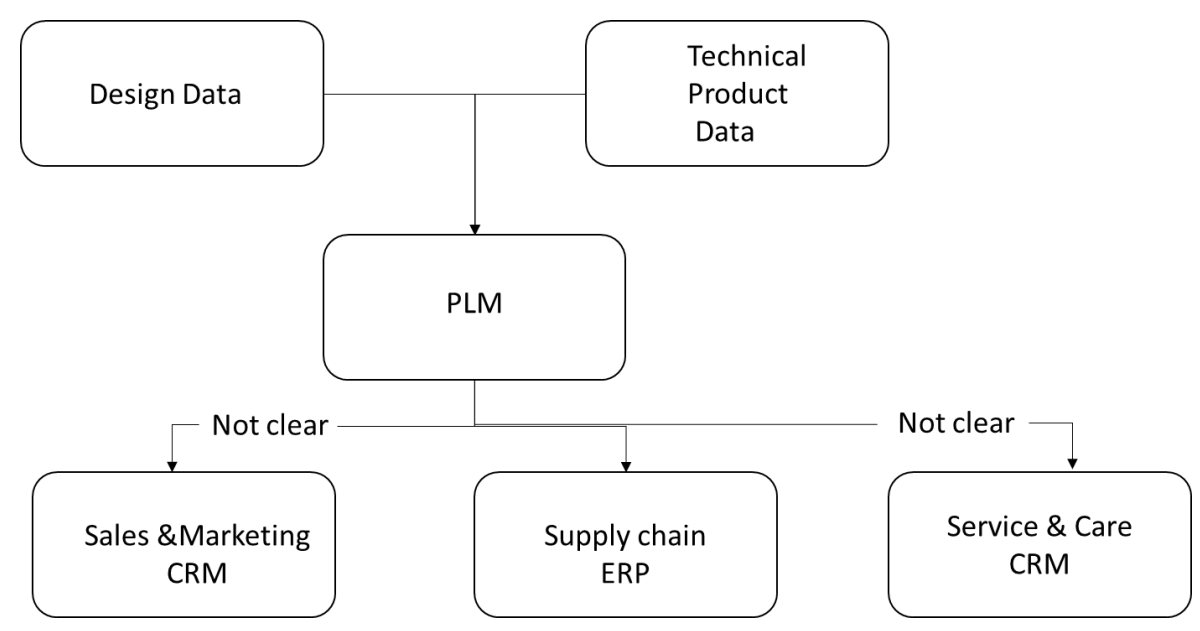

Fig. 7. Categories of main product data in company $A$

The main product data categories in company A included the most mentioned data elements and how they were linked. Respondents at company A also referred frequently to product documentation, which was a clear customer requirement. Empirical analysis suggests that the actual business drivers in company A are linked, and as with common product data structures, these drivers should be described. The analysis clearly identifies the need for a framework to managing the product master data once the product has been launched.

Finding 1. Technical perspectives, to a certain extent, are not enough for one product definition, where the master data is created once.

Finding 2. Effective use of information systems is necessary to integrate business processes and to obtain adequate support for determining one product data from the corporate strategy.

\section{Company $B$}

Company B was selected mainly for its superior capability to launch new services. Although companies A and B were not competitors, the latter was much faster at developing new services. During the interview, the R\&D manager explained, "a new service can be launched in a week when it is based on an existing technology." To a certain extent, clear links were evident to the service strategy of the company. However, the links were not fully optimised as the company was renewing its internal IT systems at the time of the interviews. Both the interviewees said that "IT system silos make the comprehensive service business challenging to manage internally." Some common service product data elements were already in use and had been productised. However, the service product data was not well managed as the related data ownership was not fully clear. The product manager explained, "The monitoring operations of big customers have been taken care of with real time monitoring. What is being monitored is the service master data used for running the service." The manager added, "Sales people have only 
price data monitored, but link to the service operations side master data and offered services is not tight."

Company B has a large footprint in the field of digitalisation of services and is a firstmover in Finland. Because B's service business was not well productised and structured, the applicability of the results was limited. The role of the business drivers was minimal and mainly visible at the lowest levels of the service BOM, at standardised levels. The reasons for standardising the lowest level of the services better than higher levels were possibly service reliability and cost optimisation. This were identified in both the interviews.

Finding 3. Adequate consideration of product data is also significant for services, which suggests that product type is not a major factor for one product data considerations, where the master data is created once.

Finding 4. Clear structure and adequate ownership are needed for effective product data considerations.

\section{Company C}

Company $\mathrm{C}$ was chosen to be a part of this study because of its mature process framework, which implied that product data formed the core of the company's business processes. Cross-industry learning opportunities were particularly attractive in this case.

Company $\mathrm{C}$ had a clear model of roles and responsibilities, which was derived from the corporate product strategy (Figure 8). The global product strategy covered and integrated all the business functions into one strategy document. The R\&D manager explained, "the journey has been ongoing for the past two years, including renewal and re-thinking the roles and responsibilities across the organisations." The company had also created a global product data governance function, where all functions had their own responsibility area. Product data owners were identified for each product, and they worked together under the framework of a data owner network (DON). The product manager added, "did not know anything about the DON before the internal project with some external support was started."

As all the business drivers were derived from the product strategy, the company $\mathrm{C}$ regularly updated its strategy, and the details of the updates were broken down to action items such as product portfolio steering actions, such as product ramp-ups and ramp downs, and decisions on new R\&D projects, whether modifications to the existing products or completely new products. 


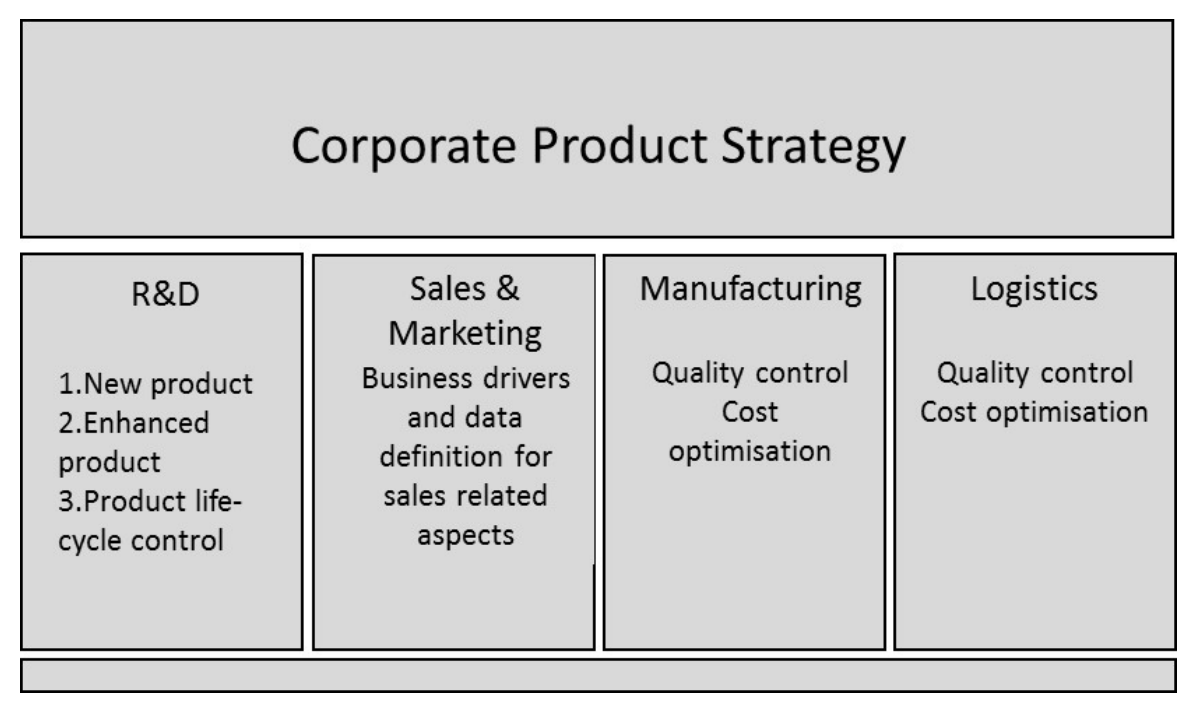

Fig. 8. Product strategy framework - Company C.

Finding 5. Certain industry environments may naturally steer towards clearer product data definition and linkages between strategy and product data because of different standards that compensate for internal deficiencies in definitions.

Finding 6. Consistent data efforts and practices such as DON can prove beneficial for one product data initiatives.

\section{Results synthesis and discussion}

Table 7 summarises the findings. The most important prerequisite to having clear product data requirements is a close link between the main business processes and new product/service development. Corporate strategy also plays an important role as seen in the case of two companies with weak links to product strategy. IT and the overall systems architecture ensures linkages among the key business drivers. Two of the three analysed companies had very loose IT architecture. The results suggest sharing business process related product data between IT systems is not a common practice, if at all. Company C was an exception in that they had implemented tight data integration policies whereas companies $\mathrm{A}$ and $\mathrm{B}$ were still developing definitions for the corporate strategy driven business drivers.

Table 7. Summarised findings from the analysed companies A, B and C.

\begin{tabular}{|l|l|l|l|}
\hline Business driver categories & Company A & Company B & Company C \\
\hline $\begin{array}{l}\text { Common, one product data } \\
\text { definition is clear }\end{array}$ & $\begin{array}{l}\text { No, only technical views exist, } \\
\text { but only for hardware. } \\
\text { Documents, service, software } \\
\text { are not defined }\end{array}$ & $\begin{array}{l}\text { No, technical service structure } \\
\text { is described, but only on a } \\
\text { case-by-case basis. }\end{array}$ & $\begin{array}{l}\text { Yes, it is defined well because } \\
\text { of regulations and quality } \\
\text { control }\end{array}$ \\
\hline $\begin{array}{l}\text { Corporate strategy and } \\
\text { product strategy are linked, }\end{array}$ & $\begin{array}{l}\text { Partially. Some of the } \\
\text { elements such as safety and }\end{array}$ & $\begin{array}{l}\text { Partially. Some of the } \\
\text { elements such as business }\end{array}$ & $\begin{array}{l}\text { Yes, the strategy is very well } \\
\text { aligned through the business }\end{array}$ \\
\hline
\end{tabular}




\begin{tabular}{|l|l|l|l|}
\hline $\begin{array}{l}\text { and there is evidence in the } \\
\text { product data as to how this } \\
\text { is done in practice }\end{array}$ & $\begin{array}{l}\text { innovation business drivers are } \\
\text { linked to product data, but } \\
\text { most links are missing }\end{array}$ & $\begin{array}{l}\text { drivers related to innovation } \\
\text { and customer segments are } \\
\text { linked to product data, but } \\
\text { most links are missing }\end{array}$ & processes and product data \\
\hline Sales-related product data & $\begin{array}{l}\text { Partially, but it is quite loosely } \\
\text { maintained in the CRM system }\end{array}$ & $\begin{array}{l}\text { Partially, but there are no } \\
\text { standards }\end{array}$ & Yes, it is well defined \\
\hline $\begin{array}{l}\text { Supply chain-related } \\
\text { product data }\end{array}$ & $\begin{array}{l}\text { Partially, but only technical } \\
\text { product data. Product-related } \\
\text { delivery data is loosely } \\
\text { understood and managed }\end{array}$ & $\begin{array}{l}\text { Partially, but limited to } \\
\text { technical service data. } \\
\text { Product-related delivery data } \\
\text { is loosely understood and } \\
\text { managed }\end{array}$ & $\begin{array}{l}\text { Yontrol and to meet cost } \\
\text { optimisation targets }\end{array}$ \\
\hline $\begin{array}{l}\text { Service/Care-related product } \\
\text { Data }\end{array}$ & $\begin{array}{l}\text { Partially, but it is maintained } \\
\text { in service system and without } \\
\text { links to original product data }\end{array}$ & $\begin{array}{l}\text { Partially, and some links are } \\
\text { used for technical service } \\
\text { product structure. }\end{array}$ & $\begin{array}{l}\text { Not applicable due to nature of } \\
\text { the product }\end{array}$ \\
\hline Product life-cycle data & $\begin{array}{l}\text { No clear process or data in } \\
\text { place }\end{array}$ & $\begin{array}{l}\text { No clear process or data in } \\
\text { place }\end{array}$ & Yes \\
\hline
\end{tabular}

Finding 7. A close link between the main business processes and new product/service development is required for clear product data requirements.

Finding 8. Sharing product data related to business processes between IT systems may be necessary for linkages among business drivers.

Product data can be defined in many ways, but what constitutes one product master data requires greater attention. Factors relevant to such product data include why it is created, who the data owners are, who the data users are, and where it is used within the company. One product master data is created only once with the mind-set that it can be used in company processes through the life-cycle of the product. The results of the study indicate that the precondition for one product data is the integration of the product master data, and product data related to business processes via PLM/PDM, CRM and ERP systems as IT applications. This can be described as the one product data triangle (Figure 9). There are two categories of business drivers that define the product master data and the product data in business processes: (1) critical common business drivers for common product data and (2) high business value drivers for product data related to the business process. Critical business drivers play a crucial role from the perspective of company strategy and operations. Such drivers are, for example, basic product data, sales price logic master data, product configuration rules, and product structure data that tightly integrates the different main processes. High business value drivers and related product data categories are crucial for business processes such as supplier data, warehouse location etc. 


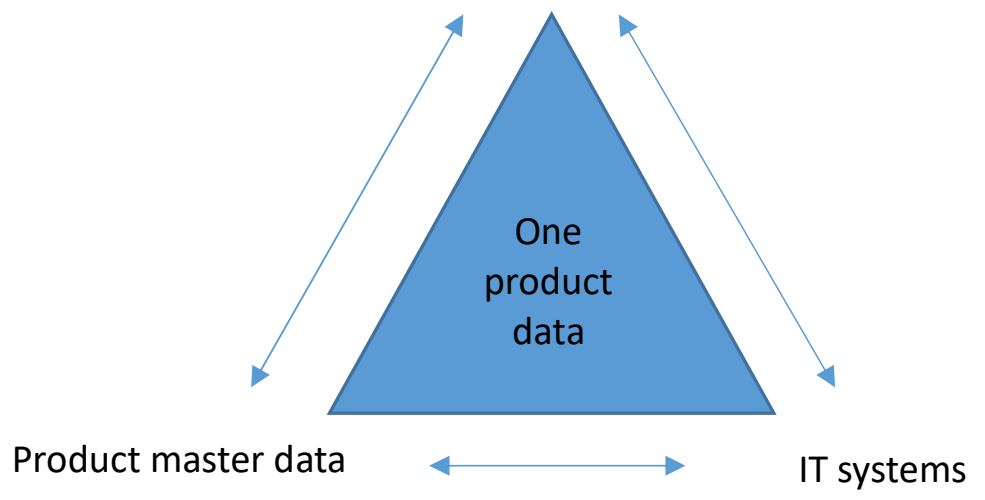

Fig. 9. One product data triangle lays the foundation of integrated product master data, business process related product data and IT systems.

Finding 9. The integration of the product master data and product data related to business process via PLM/PDM, CRM and ERP systems is a precondition for one product data - master data that is created once and processed through the product lifecycle.

Product master data creation is a part of the NPD process deliverables. This data is validated over different development phase milestones and steering group meetings to ensure the deliverable content meets the use phase expectations of the business processes. This also means that corporate management exerts considerable influence over the product master data to ensure that the critical business drivers are defined correctly before releasing the product data to business processes.

Product master data is often stored in PDM/PLM systems. A master-slave logic is needed to arrive at a situation where the product master data is created only once and then used by multiple business processes and IT systems. A product data master system such as PDM/PLM can act as a centralised storing and sharing medium towards the slave systems in business processes. The product data that comes from the PDM system is taken in as such, whilst some new business process related product data need to be added to carry out the desired business process transactions such as sales order entry, purchase orders, work orders, stock movements, shipping and installation of the product. This way the critical one product data remains the same for all. Product data records also have a life-cycle aspect, and it is the role of the product data master, the PDM system, to execute the changes across the system landscape and business processes.

The critical, one product master data is comparable to human DNA. Each product has its own common data attributes and values, which are also mapped to the product DNA, the product master data. At the same time, each product is a unique entity and its own life-cycle (Figure 10). 


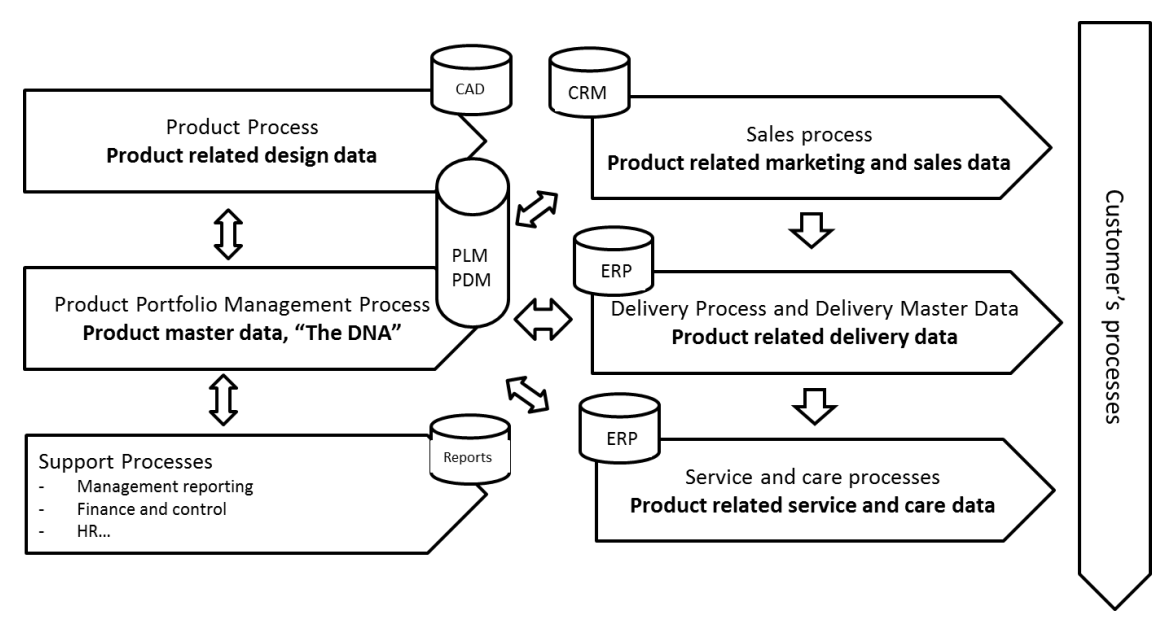

Fig. 10. Product master data, the DNA, business process related product data in integrated business processes and IT systems.

Finding 10. Product master data should be created only once and then used by the business processes and IT systems in a manner that mimics the master-slave logic.

In terms of critical business drivers, i.e. the product DNA, a $100 \%$ data quality mind-set is needed for completeness, relevance and timeliness of critical data. This means that data will be created, updated and removed within the product life-cycle. In other words, data quality will be monitored after the data has been released from the PDM/PLM system to other IT systems in business processes. Product data monitoring should occur in real time as deviations in data quality can break the product DNA. All organisations should have a common understanding about the criticality of one product data given the frequent and continuous product data changes from the business side.

Efforts should be made to ensure that the high business value drivers and related one product data are maintained at a good quality level. Whereas the quality of the product master data should be $100 \%$, for business process related product data, the target quality can vary according to the criticality of each driver from the perspective of the strategy.

In extant literature, strategy process, MDM and product portfolio data management discuss business drivers and master data as separate topics (Cooper, 2001; Stark, 2004). The link from strategy process to one product data has not been explored. This study bridges the gap by describing how business drivers are linked to one product data via product master data, business process related product data in integrated business processes and IT systems.

The key contribution of this work is the defining of a pathway from strategy to one product data, with clear evidence that when one product data is not under control, it reflects in daily activities. The vast number of information sources required to put together one product data requirements is especially noteworthy.

Linking business strategy and customer needs to one product data is not an easy task mainly because of deficient PDM and PPM practices. Common strategy processes that clearly feature PDM and PPM could not be empirically identified. This can be attributed to the possibility that people within organisations still work within their silos and are 
unable to visualise the benefits of digital product information and related product lifecycle management activities. Creating high quality one product data once and using it across the company business processes offer enormous improvement opportunities and save wasteful activities.

\section{Conclusions}

Practices for deriving master data from the corporate strategy are essential for companies. This is particularly true because of the growing emphasis on PDM for creating and managing product master data and business process related product data. Business drivers should be understood from a corporate strategy perspective to capture product data in relevant systems in a straightforward manner. A novel contribution of this study is that it clarifies the foundations for determining one product data together with the sources of the requirements. The proposed one product data triangle is founded on the three pillars of product master data, business process related product data, and integration of business processes based on IT systems. Each factor impacts the other two. IT systems and related configurations should be based on the business process architecture, which defines the options for product data classification. New understanding on the linkages with business drivers is created by analysing product data definitions, whereas main business processes are used to support categorisation of the product data. Unique contribution involves discussing master data considerations in the context of business processes and IT systems. This study highlights how the integration of the product master data, and business process related product data by the PLM/PDM, CRM and ERP systems is a precondition for one product data. The analysis of the practices of three companies support the understanding how new product business drivers impact the product data requirements.

Product data requirements are drawn from the corporate strategy, which is also the source of business and product strategy. These business drivers (requirements) determine how PPM, product development, sales, delivery (SC) and service processes operate. Traditionally, product data has been used to describe technical product aspects. In addition to technical aspects, product data should be defined for business processes such as sales, delivery and service. The role of the business drivers is to make sure that these requirements are being met. This study argues that the effective use of information systems is necessary to integrate business processes and to obtain adequate support for determining one product data from the corporate strategy. This study also indicates that sharing business process related product data between IT systems may be necessary for linkages among business drivers.

Business drivers highlight the need for making the product master data understandable in layman terms. This is needed because the individuals responsible for product data definition are typically not master data experts. Nevertheless, companies should invest efforts to ensure that the business drivers are met before launching new products.

Acknowledging the importance of business drivers is vital to the definition of the one product data concept. Secondly, prioritisation is essential as some product data related to business process is more valuable than others. Product master data refers to the product's DNA - such unchanging data that defines the product itself and is common to business processes. Business process related product data specifies how the product is 
marketed, sold, supplied, manufactured, distributed, etc. A combination of the business drivers, product master data and business process related product data are needed to formulate the concept of one product data across all business processes. This study emphasises how product master data should be created only once and then used by the business processes and IT systems in a manner that mimics the master-slave logic. In practice, one product data is closely integrated with product master data, business process related product data, and IT systems.

Managers need to realise that if the capability to translate business drivers to one product data requirements does not work for both new and existing products, it is likely that implementing any new strategies that are product data intensive will not be easy. Ultimately, organisations should recognise one product data and its benefits and accordingly execute their corporate strategy. The top and the middle management can benefit from the results of this study when considering the important question of "Do we follow our strategy with our products?"

\section{Limitations and scope for future research}

A limitation of this study is that product data requirements, business drivers and the product data concept were qualitatively analysed by focusing only on three companies. A certain level of subjectivity may have also affected interviewee responses. The number of interviews conducted also poses a limitation; however, it is assumed to be adequate for drawing conclusions of a qualitative nature. Misinterpretations by researchers in a qualitative study can also take away from the findings; however, multiple researchers confirming the findings reduces the likelihood. Further, some relevant discussion included in the previous literature may have been missed, potentially influencing the conclusions. The lack of statistical tests can also be considered a limitation. In future, researchers can link business strategy and customer needs to one product data definition. They can utilise the design for excellence, $\operatorname{Df}(\mathrm{x})$, type of logic to build roles and responsibilities that they truly cover the life-cycle properties of product data. This would entail measuring the overall quality of the design apart from time as a productivity measure. The relationship of quality, cost and end-to-end efficiency would also need to be defined. In addition, the new value of Internet of things would be an interesting topic with a suitable data-specific focus. Lastly, the role of the PLM/PDM processes and applications could be further studied to understand which business process related product data links back to product master data system to transform the traditional PLM/PDM systems into a modern PPM system.

\section{References}

Addo-Tenkorang, R. and Helo, P.T. (2014) "ERP SaaS value chain: a proposed SaaS model for manufacturing SCM networked activities", International Journal of Business Information Systems, Vol. 17, No. 3, pp.355-372.

Ala-Risku, T. (2009) Installed Base Information: Ensuring Customer Value and Profitability after the Sale. Dissertation thesis, Helsinki University of Technology. Doctoral Dissertation Series 2009/6.

Arlbjørn, J.S., Wong, C.Y. and Seerup, S. (2007) 'Achieving competitiveness through supply chain integration', International Journal of Integrated Supply Management, Vol. 3, No. 1, pp.4-24. 
Arora, B. and Rahman, Z. (2017) 'Assessing the impact of information technology capability on firm profitability and market value in emerging economies: a study from India', International Journal of Business Information Systems, Vol. 25, No.2, pp.192-212.

Baghdadi, Y. (2014) 'Modelling business process with services: towards agile enterprises', International Journal of Business Information Systems, Vol. 15, No. 4, pp. 410-433.

Bai, C. and Sarkis, J. (2013) 'A grey-based DEMATEL model for evaluating business process management critical success factors', International Journal of Production Economics, Vol. 146, No. 1, pp.281-292.

Brettel, M., Friederichsen, N., Keller, M. and Rosenberg, M. (2014) 'How Virtualization, Decentralization and Network Building Change the Manufacturing Landscape: An Industry 4.0 Perspective', International Journal of Mechanical, Aerospace, Industrial, Mechatronic and Manufacturing Engineering, Vol. 8, No. 1, pp.37-44.

Bruch, J. and Bellgran, M. (2014) 'Integrated Portfolio Planning of Products and Production Systems', Journal of Manufacturing Technology Management, Vol. 25, No. 2, pp.155-174.

CIMdata (2002) Product Lifecycle Management: Empowering the Future of Business, A CIMdata Report, CIM Data Inc. Ann Arbor, MI.

Caballero, I., Caro, A., Calero, C. and Piattini, M. (2008) 'IQM3: information quality management maturity model', Journal of Universal Computer Science, Vol. 14, No. 22, pp.3658-3685.

Chauhan, S. and Jaiswal, M. (2015) 'Exploring factors affecting service quality of ERP on cloud: a revelatory case study', International Journal of Business Information Systems, Vol. 19, No. 1, pp. 87-102.

Cleven, A. and Wortmann, F. (2010) 'Uncovering four strategies to approach master data management', 43rd Hawaii International Conference on System Sciences in Koloa, Kaua'I, Hawaii, IEEE Computer Society, Los Alamitos, CA, pp. 1-10.

Cooper, R.G., Edgett, S.J. and Kleinschmidt, E.J. (1997) 'Portfolio management in new product development: Lessons from the Leaders-I', Research technology management, Vol. 40, No. 5, pp.16-28.

Cooper, R.G., Edgett, S.J. and Kleinschmidt, E.J. (1999) 'New product portfolio management: Practices and performance', Journal of Product Innovation Management, Vol. 16, No. 4, pp.333-351.

Cooper, R.G. (2001) Winning at new products: accelerating the process from idea to launch, 3rd ed. Perseus Publishing Cambridge, Mass.

Cooper, R.G., Edgett, S.J. and Kleinschmidt, E.J. (2001) 'Portfolio Management for new product development: Results of an industry practices study', $R \& D$ management, Vol. 31, No. 4, pp.361-380.

Cooper, R.G., Edgett, S.J. and Kleinschmidt, E.J. (2004) 'Benchmarking Best NPD Practices-II', Research Technology Management, Vol. 47, No. 3, pp. 50-59.

Cooper, R. (2008) 'Perspective: The Stage-Gate, Idea-to-Launch Process - Update, What's New and NexGen Systems', The Journal of Product Innovation Management, Vol. 25, No. 3, pp.213-232.

Corallo, A., Margherita, A., Scalvenzi, M. and Storelli, D. (2010) 'Building a process-based organization: the design roadmap at Superjet', International. Knowledge and Process Management, Vol. 17, No. 2, pp.49-61.

Crnkovic, I. (2002) Implementing and Integrating Product Data Management and Software Configuration Management. Artech House, Norwood, MA.

de Boer, F.B., Muller C.J. and ten Caten C.S. (2015) 'Assessment model for organizational business process maturity with a focus on BPM governance practices’, Business Process Management Journal, Vol. 21, No. 4, pp.908-927.

de Lima E.P., da Costa S.E.G, Angelis J.J. and Munik, J. (2012) 'Performance Measurement Systems: A consensual analysis of their roles', International Journals of Production Economics, Vol. 146, No. 2, pp.524-542.

de Morais, R.M., Kazan, S., de Pádua, S.I.D. and Costa, A.L. (2014) 'An analysis of BPM lifecycles: from a literature review to a framework proposal', Business Process Management Journal, Vol. 20, No. 3, pp.412 - 432.

DeToro, I. and McCabe, T. (1997) 'How to stay flexible and elude fads', Quality Progress, Vol. 30, No. 3, pp.5560.

Do, N., Choi, I. and Jang, M. (2002) 'A Structure-Oriented Product Data Representation of Engineering Changes for Supporting Integrity Constraints', International Journal of Advanced Manufacturing Technology, Vol. 20, No. 8, pp. 564-570.

Do, N., Choi, I.J. and Song, M. (2008) 'Propagation of engineering changes to multiple product data views using history of product structure changes', International Journal of Computer Integrated Manufacturing, Vol. 21, No. 1, pp.19-32.

Drucker, P.F. (2011) People and Performance: The Best of Peter Drucker on Management, Routledge, New York, NY. 
Edvardsson, B., Gustafsson, A. and Roos, I. (2005) 'Service Portraits in Service Research: a Critical Review', International Journal of Service Industry Management, Vol. 16, No. 1, pp.107-121.

Fine, C.H. and Hax, A.C. (1985) 'Manufacturing strategy: a methodology and an illustration', Interfaces, Vol 15, No. 6, pp. 28-46.

Fujimoto, J., Umeda, Y., Tamura, T., Tomiyama, T. and Kimura, F. (2003) 'Development of Service-Oriented Products Based on the Inverse Manufacturing Concept', Environmental Science and Technology, Vol. 37, No. 23, pp.53985406.

Gardner, R. (2004) The process-focused organization: a transition strategy for success. ASQ Quality Press, Milwaukee, WI.

Genaroro, A.F.S. and Lourero, G. (2015) 'Stakeholder management as an approach to integrated management system, Transdisciplinary lifecycle analysis of systems', Proceedings of the $22^{\text {nd }}$ ISPE Inc. International Conference on Concurrent Engineering.

Gomez, J.M., Bedolla, J.S., Ricci, F. and Chiabert, P. (2014) 'Validation process model for product life-cycle management', International Journal of Product Lifecycle Management, Vol. 7, No. 2/3, pp.230-246.

Gosling, J. and Naim, M.M. (2009) 'Engineer-to-order supply chain management: A Literature review and research agenda', International Journal of Production Economics, Vol. 122, No. 2, pp.741-754.

Gunasekaran, A. and Sandhu, M. (2010) Handbook of business information systems. World Scientific publishing, Singapore.

Haapasalo, H., Ingalsuo, K. and Lenkkeri, T. (2006) 'Linking Strategy into Operational Management - A Survey of BSC Implementation in Finnish Energy Sector', Benchmarking: An International Journal, Vol. 13, No. 6, pp.701-717.

Haines, S. (2009) The Product Manager's Desk Reference. USA: McGraw-Hill Professional.

Hammer, M. (2002) 'Process management and the future of six sigma', Engineering Management Review, Vol. 30, No. 4, pp.21-32.

Haug, A., Zachariassen, F., van Liempd, D. (2011) 'The costs of poor data quality', Journal of Industrial Engineering and Management, Vol. 4, No. 2, pp.168-193.

Harmon, P. (2006) 'Process and strategy, Business Process Trends', Monthly E-mail Advisors, Vol.4, No. 6, pp.13.

Harris, B. (1996) 'Business Strategy and the Role of Engineering Data Management: A Literature Review and Summary of the Emerging Research Questions', Journal of Engineering Manufacture, Vol. 210, No. 3, pp.207220.

Hazen, B.T., Boone, C.A., Ezell, J.D. and Jones-Farmer, L.A. (2014) 'Data quality for data science, predictive analytics, and big data in supply chain management: An introduction to the problem and suggestions for research and applications', International Journal of Production Economics, Vol. 154, pp.72-80.

Hüner, K.M., Schierning, A., Otto, B. and Osterle, H. (2011) 'Product data quality in supply chains: the case of Beiersdorf', Electronic Markets, Vol. 21, No. 2, pp.141-154.

Hvam, L., Mortensen, N.-H. and Riis, J. (2008) Product Customization. Springer, New York, NY.

Jain, V. (2016) 'Conceptualising ERP systems' value as a multidimensional formative construct', International Journal of Business Information Systems, Vol. 21, No. 4, pp.439-461.

Jinsong, Z., Qifu, W., Li, W. and Yifang, Z. (2005) 'Configuration-oriented product modelling and knowledge management for made-to-order manufacturing enterprises', International Journal of Advanced Manufacturing Technology, Vol. 25, No. 1, pp.41-52.

Johansson, E. (2007) 'Towards a design process for materials supply systems', International Journal of Operations \& Production Management, Vol. 27, No. 4, pp.388-408.

Johansson, E. and Johansson, M.I. (2004) 'The information gap between design engineering and materials supply systems design', International journal of Production Research, Vol. 42, No. 17, pp.3787-3801.

Johansson, E. and Medbo, L. (2004) 'On the use of product data in the design of the materials supply system', Journal of Manufacturing Technology Management, Vol. 15, No. 7, pp.641-650.

Joshi, A. (2007) 'MDM governance: a unified team approach', Cutter IT Journal, Vol. 20 No. 9, pp.30-35.

Johnston, R. and Clark, G. (2001) Service Operations Management. Pearson Education, United Kingdom.

Kemppainen, T. (2010) Product Data Ownership Network. Master's Thesis, University of Oulu, Department of Process Engineering.

Kersten, B. and Verhoef, C. (2003) 'IT portfolio management: a banker's perspective on IT', Cutter IT Journal, Vol.16, No. 4, pp.34-40. 
Keshavarz, E., Heydari, T., Rohani, A. and Bagheri, S.M. (2014) "Using fuzzy AHP and fuzzy TOPSIS methods for prioritisation of technological competencies to maximise the financial and non-financial performance", International Journal of Business Information Systems, Vol. 16, No. 3, pp.297-320.

King, D.L., Case, C.J. and Premo, P.M. (2010) 'Current Misson Statement Emphasis: Be Ethical and Go Global', Academy of Strategic Management Journal, Vol. 9, No. 2, pp.71-87.

Kock, N. (2005) Business process improvement through e-collaboration: knowledge sharing through the use of virtual groups. IGI publishing global, London.

Kohlbacher, M. (2010) 'The effects of process orientation: a literature review', Business Process Management Journal, Vol. 16, No. 1, pp.135-152.

Kropsu-Vehkapera, H., Haapasalo, H., Harkonen, J. and Silvola, R. (2009) 'Product data management practices in high-tech companies', Industrial Management \& Data Systems, Vol. 109, No. 6, pp.758-774.

Kropsu-Vehkapera, H., Haapasalo, H. and Vahtiala, M. (2010) 'Exploiting product data management through product lifecycle for intangibles', Proceedings of the 17th Annual EurOMA Conference, Managing Operations in Service Economies, June 6. - 9.2010, Porto, Portugal.

Kropsu-Vehkapera, H. and Haapasalo, H. (2011) 'Defining product data views for different stakeholders', Journal of Computer Information Systems, Vol. 52, No. 2, pp.61-72.

Kropsu-Vehkapera, H. (2012) Enhancing understanding of company-wide product data management in ICT companies. Doctoral dissertation. Acta Universitas Ouluensis C Technica 418, University of Oulu, Finland.

Lee, R.G. and Dale, B.G. (1998) 'Business process management: a review and evaluation', Business process management journal, Vol. 4, No. 3, pp.214-225.

Lee, B.-E. and Suh, S.-H. (2009) 'An architecture for ubiquitous product life-cycle support system and its extension to machine tools with product data model', International Journal of Advanced Manufacturing Technology, Vol. 42, No. 5-6, pp.606-620.

Leffingwell, D. (2007) Scaling Software Agility: Best Practices for Large Enterprises. Boston, MA, Addison-Wesley.

Leser, F., Alt, R. and Osterle, H. (2005) 'Implementing Collaborative Process Management: The Case of Net-Tech', International Journal of Cases on Electronic Commerce, Vol. 1, No. 4, pp.1-18.

Li, H., Ji, Y., Luo, G. and Mi, S. (2016) 'A modular structure data modeling method for generalized products', The International Journal of Advanced Manufacturing Technology, Vol. 84, No. 1-4, pp.197-212.

Li, Y., Wan, L. and Xiong, T. (2011) 'Product data model for PLM system', The International Journal of Advanced Manufacturing Technology, Vol. 55, No. 9, pp.1149-1158.

Lovelock, C. and Gummesson, E. (2008) 'Whither Services Marketing? In Search of a new paradigm and fresh perspectives', Journal of Service Research, Vol. 7, No. 1, pp.20-41.

Madison, D. (2005) Process Mapping, Process Improvement and Process Management. Paton Press, Chico, CA.

Malihi, E. and Aghdasi, M. (2014) *A decision framework for optimisation of business processes aligned with business goals', International Journal of Business Information Systems, Vol. 15, No. 1, pp.22-42.

Mani, R.V.S., Baul, U., Mohanty, R.P. and Rajkumar, T.M. (2013) 'An empirical study of information technology infrastructure capability and its impact on digitally enabled customer management processes in life insurance companies', International Journal of Business Information Systems, Vol. 14, No. 4, pp.461479.

Margherita, A. (2013) 'Business process management system and activities, Two integrative definitions to build and operational body of knowledge', Business Process Management Journal, Vol. 20, No. 5, pp. 642-662.

McCutcheon, D. and Meredith, J.R. (1993) 'Conducting case study research in operations management', Journal of Operations Management, Vol. 11, No. 3, pp.239-256.

McGrath, M.E. (2001) Product Strategy for high technology companies - Accelerating your business to web speed. 2nd ed. McGraw Hill Professional, New York, NY.

Meeamol, S., Rodpetch, V., Rueangsuwan, S. and Lin, B. (2011) 'Measuring the Firm's Financial Value: Interrelationships with the Board Structure', International Journal of Performance Measurement, Vol. 1, No. 1, pp.59-78.

Meyliana, Hidayanto, A.N. and Budiardjo, E.K. (2016) 'The critical success factors for customer relationship management implementation: a systematic literature review', International Journal of Business Information Systems, Vol. 22, No. 2, pp. 131-174.

Merton, R., Fiske, M. and Kendall, PP. (1990) the Focused Interview: A Manual of Problems and Procedures, 2nd ed. New York: The Free Press. 
Monk, E.F. and Wagner, B.J. (2009) Concepts in Enterprise Resource Planning. $3^{\text {rd }}$ Ed., Cengage Learning, USA.

Neubauer, T. (2009) 'An empirical study about the status of business process management', Business Process Management Journal, Vol. 15, No. 2, pp.166-183.

Nilsson, P. and Fagerstrom, B. (2006) 'Managing stakeholder requirements in a product modelling system', Computers in Industry, Vol. 57, No. 2, pp.167-177.

Ofner, M.H., Straub, K., Otto, B. and Oesterle, H. (2013) 'Management of the master data lifecycle: a framework for analysis', Journal of Enterprise Information Management, Vol. 26, No. 4, pp.472-491.

Otto, B. and Reichert, A. (2010) 'Organizing master data management: findings from an expert survey', Proceedings of the 2010 ACM Symposium on Applied Computing, Sierre, Switzerland, March 22-26, pp.106-110.

Otto, B. (2012) 'How to design the master data architecture: Findings from a case study at Bosch', International Journal of Information Management, Vol.32, No. 4, pp.337-346.

Otto, B., Lee, Y.W. and Caballero, I. (2011) 'Information and data quality in networked business', Electronic Markets, Vol. 21, No. 2, pp.79-81.

Pan, X.-W., Zhu, X.-Y., Ji, Y.-J., Yang Y., Wu, Y.-M. (2014) 'An information integration modelling architecture for product family life-cycle in mass customisation', International Journal of Computer Integrated Manufacturing, Vol. 27, No. 9, pp.869-886.

Patton, M.Q. (2002) Qualitative Research and Evaluation Methods, 3rd edition, Thousand Oaks, Sage Publications.

Pham, T.D., Dimov, S.S., Setchi, R.M. (1999) 'Intelligent product manuals', Journal of Systems and Control Engineering, Vol. 213, No. 1, pp.65-76.

Philpotts, M. (1996) 'An introduction to the concepts, benefits and terminology of product data management', Industrial Management \& Data Systems, Vol. 96, No. 4, pp.11-17.

Puzey, M. and Latham, S. (2016) 'Enabling operational excellence through the effective management of master data', The APPEA Journal, Vol. 56, No. 2, pp.575-575.

Rajarathinam, V., Chellappa, S. and Nagarajan, A. (2015) 'Conceptual Framework for the Mapping of Management Process with Information Technology in a Business Process', Scientific World Journal, Vol. 2015, Article 983832, pp.1-7.

Rumelt, R.P. (1980) The Evaluation of Business Strategy, In Glueck, W.F. Strategic Management and Business Policy, McGraw-Hill, New York, NY, pp.359-367.

Sajadfar, N., Triana, L.C. and Ma, Y. (2014) 'Interdisciplinary Semantic Interactions within a Unified Feature Model for Product Cost Estimation', International Journal of Mechanical Engineering and Mechatronics, Vol. 2, No. 1, pp. 1929-2724.

Salonen, N.V. (2006) 'Dynamic Product Structure Configuration Specification Management', NordDesign 2006, August 16-18, Reykjavik, Iceland, pp.120-127.

Salvador, F. and Forza, C. (2007) 'Principles for efficient and effective sales configuration design', Journal of Mass Customisation, Vol. 2, Nos. 1/2, pp.114-127.

Saravanan, D. and Joseph, D. (2016) 'Implementation and cultural issues going together for successful adoption of ERP systems', International Journal of Business Information Systems, Vol. 23, No. 1, pp. 87-96.

Scheidt, L.G. and Zong, S. (1994) 'An approach to achieve reusability of electronic modules', Proceedings of IEEE International Symposium on Electronics \& the Environment, IEfEE. San Francisco, CA, USA, pp.331-336.

Sharma, S., Shandilya, R., Patnaik, S. and Mahapatra, A. (2016) "Leading NoSQL models for handling Big Data: a brief review", International Journal of Business Information Systems, Vol. 22, No. 1, pp. 1-25.

Siddiqui, Q.A., Burns, N.D. and Backhouse, C.J. (2004) 'Implementing product data management the first time', International Journal of Computer Integrated Manufacturing, Vol. 17, No. 6, pp.520-533.

Siggelkow, N. (2007) 'Persuasion with case studies', Academy of Management Journal, vol. 50, no. 1, pp.20-24.

Silvola, R., Jaaskelainen, O., Kropsu-Vehkapera, H. and Haapasalo, H. (2011) 'Managing one master data - challenges and preconditions', Industrial Management \& Data Systems, Vol. 111, No. 1, pp.146-162.

Silvola, R., Harkonen, J., Vilppola, O., Kropsu-Vehkapera, H. and Haapasalo, H. (2016) 'Data quality assessment and improvement', International Journal of Business Information Systems, Vol. 22, No. 1, pp.62-81.

Schierholz, R., Kolbe, L.M. and Brenner, W. (2007) 'Mobilizing customer relationship management: A journey from strategy to system design', Business Process Management Journal, Vol. 13, No. 6, pp.830-852.

Shahin, A., Pool, J.K. and Poormostafa, M. (2014) 'Evaluating and ranking hotels offering e-service by integrated approach of Webqual and fuzzy AHP', International Journal of Business Information Systems, Vol. 15, No. 1, pp.84-104. 
Sharma, S. and Shah, B. (2015) 'Thinking cloud-enabled adept and agile supply chain for SMEs: a conceptual study', International Journal of Business Information Systems, Vol. 17, No. 3, pp.342-365.

Smith, T.M. and Reece, J.S. (1999) 'The relationship of strategy, fit, productivity, and business performance in a services setting', Journal of Operations Management, Vol. 17, No. 2, pp.145-161.

Smith, H.A. and McKeen, J.D. (2008) 'Developments in Practice XXX: Master Data Management: Salvation Or Snake Oil?', Communications of the Association for Information Systems, Vol. 23, No.4. pp.63-72.

Sonzini, M.S., Vegetti, M. and Leone, H. (2015) 'Towards ontology for product version management', International Journal of Product Lifecycle Management, Vol. 8, No.1, pp.90-97.

Sung, Y.-K., Lee, J. Yi, J.-S. and Son, J. (2017) "Establishment of Growth Strategies for International Construction Firms by Exploring Diversification-Related Determinants and Their Effects", Journal of Management in Engineering, Vol. 33, No.5, pp. 16-28.

Sriti, M.F., Assouroko, I., Ducellier, G., Boutunaud, P. and Eynard, B. (2015) 'Ontology-based approach for product information exchange', International Journal of Product Lifecycle Management, Vol. 8, No.1, pp.123.

Stark, J. (2004) Product lifecycle management: 21st century paradigm for product realization. Springer, New York, NY.

Stiles, P. (2001) 'The Impact of the Board on Strategy: An Empirical Examination', Journal of Management Studies, Vol. 38, No. 5, pp.627-650.

Strong, D.M., Lee, Y.W. and Wang, R.Y. (1997) 'Data Quality in Context', Communications of the ACM, Vol. 40, No. 5, pp.103-110.

Saaksvuori, A. (2011) PLM vision 2016 and beyond. Sirrus Capital Ltd, Helsinki, Finland.

Saaksvuori A. and Immonen, A. (2008) Product Lifecycle Management. 3rd Edition, Springer-Verlag, Berlin Heidelberg.

Tao, F., Cheng, J., Qi, Q., Zhang, M., Zhang, H. and Sui, F. (2017) "Digital twin-driven product design, manufacturing and service with big data", The International Journal of Advanced Manufacturing Technology, available online, pp.1-14

Terzi, S., Bouras, A., Dutta, D., Garetti, M. and Kiritsis, D. (2010) 'Product lifecycle management - from its history to its new role', International Journal of Product Lifecycle Management, Vol. 4, No. 4, pp.360-389.

Tian, G. and Quan, L. (2008) 'An improved framework of business process management system which integrating the strategy management', Management Science and Engineering, ICMSE 2008, 15th Annual Conference Proceedings. International Conference on IEEE, pp.256-261.

Tidstam, A. and Malmqvist, J. (2015) 'A systematic process for developing configuration rules', International Journal of Product Lifecycle Management, Vol. 8, No. 1, pp.46-64.

Tolonen, A., Harkonen, J., and Haapasalo, H. (2014) 'Product portfolio management - Governance for commercial and technical portfolios over life-cycle', Technology and Investment, Vol. 5, No. 4, pp.173-183.

Tolonen, A., Harkonen, J., Verkasalo, M. and Haapasalo, H. (2015a) 'Product portfolio management process over horizontal and vertical portfolios', International Journal of Product Life-cycle Management, Vol. 8, No. 3, pp.189-215.

Tolonen, A., Shahmarichatghieh, M., Harkonen, J. and Haapasalo, H. (2015b) 'Product portfolio management Targets and key performance indicators for product portfolio renewal over life-cycle', International Journal of Production Economics, Vol. 170, pp.468-477.

Tu, Y.L., Xie, S.Q. and Kam, J.J. (2006) 'Rapid one-of-a-kind production', International Journal of Advanced Manufacturing Technology, Vol. 29, No. 5, pp.499-510.

Ulrich, K. and Eppinger, S. (2012) Product design and development. McGraw-Hill. New York, NY.

Varadarajan, P.R. (1994) 'Delineating the scope of corporate, business, and marketing strategy', Journal of Business Research, Vol. 31, No. 2-3, pp.93-105.

Vilminko-Heikkinen, R. and Pekkola, S. (2017) "Master data management and its organizational implementation: An ethnographical study within the public sector", Journal of Enterprise Information Management, Vol. 30, No. 3, pp.454-475.

Weber, K., Otto, B. and Osterle, H. (2009) 'One Size Does Not Fit All - A Contingency Approach to Data Governance', Journal of Data and Information Quality, Vol. 1, No. 1, Article 4.

Wende, K. (2007) 'A Model for Data Governance - Organising Accountabilities for Data Quality Management', 18th Australasian Conference on Information Systems, 5-7 Dec 2007, Toowoomba, pp.417-425. 
Wang, R.Y. and Strong, D.M. (1996) 'Beyond Accuracy: What Data Quality Means to Data Consumers', Journal of Management Information Systems, Vol. 12, No. 4, pp.5-34

Weerd, I., Brinkkemper, S., Nieuwenhuis, R., Versendaal, J. and Bijlsma, L. (2006) 'Towards a Reference Framework for Software Product Management', Requirement Engineering, 14th IEEE International Requirements Engineering Conference, Minneapolis US, pp.319-322.

Wheelen, T.L. and Hunger, J.D. (2006) Strategic management and business policy: concepts, 10th ed. Pearson Prentice-Hall, Upper Saddle River, NJ.

Williams, L.S. (2008) 'The Mission Statement, A Corporate Reporting Tool with a Past, Present, and Future', Journal of Business Communication, Vol. 45, No. 2, pp. 94-119.

Wu, Z.Y., Ming, X.G., Wang, Y.L. and Wang, L. (2014) 'Technology solutions for product lifecycle knowledge management: framework and a case study', International Journal of Production Research, Vol. 52, No. 21, pp.6314-6334.

Wynn, M.G. and Brinkmann, D. (2016) 'Exploiting Business Intelligence for Strategic Knowledge Management: A German Healthcare Insurance Industry Case Study', International Journal of Business Intelligence Research, Vol. 7, No. 1. pp.11-24.

Xiang, F., Yin, Q., Wang, Z., Jiang, G.Z. (2017) 'Systematic method for big manufacturing data integration and sharing', The International Journal of Advanced Manufacturing Technology, Available online, pp.1-14.

Yeoh, W. and Koronios, A. (2010) 'Critical Success Factors for Business Intelligence Systems', The Journal of Computer Information Systems, Vol. 50, No. 3, pp.23-32.

Yin, R.K. (2003) Case study research: Design and methods. 3rd ed., Beverly Hills, CA: Sage Publications Inc. 